\title{
Kinetic Studies on State of the Art Solid Oxide Cells \\ A Comparison between Hydrogen/Steam and Reformate Fuels
}

Njodzefon, Jean-Claude; Graves, Christopher R.; Mogensen, Mogens Bjerg; Weber, André; Hjelm, Johan

Published in:

Journal of The Electrochemical Society

Link to article, DOI:

10.1149/2.1201613jes

Publication date:

2016

Document Version

Publisher's PDF, also known as Version of record

Link back to DTU Orbit

Citation (APA):

Njodzefon, J-C., Graves, C. R., Mogensen, M. B., Weber, A., \& Hjelm, J. (2016). Kinetic Studies on State of the Art Solid Oxide Cells: A Comparison between Hydrogen/Steam and Reformate Fuels. Journal of The Electrochemical Society, 163(13), F1451-F1462. https://doi.org/10.1149/2.1201613jes

\section{General rights}

Copyright and moral rights for the publications made accessible in the public portal are retained by the authors and/or other copyright owners and it is a condition of accessing publications that users recognise and abide by the legal requirements associated with these rights.

- Users may download and print one copy of any publication from the public portal for the purpose of private study or research.

- You may not further distribute the material or use it for any profit-making activity or commercial gain

- You may freely distribute the URL identifying the publication in the public portal 


\title{
Kinetic Studies on State of the Art Solid Oxide Cells: A Comparison between Hydrogen/Steam and Reformate Fuels
}

(ESS)

\author{
Jean-Claude Njodzefon, ${ }^{\mathrm{a}, \mathrm{z}}$ Christopher R. Graves, ${ }^{\mathrm{a}, *}$ Mogens B. Mogensen, ${ }^{\mathrm{a}, * *}$ \\ André Weber, ${ }^{\mathrm{b}, *}$ and Johan Hjelm ${ }^{\mathrm{a}, *}$ \\ ${ }^{a}$ Department of Energy Conversion and Storage, Technical University of Denmark, Ris $\phi$ Campus, \\ DK-4000 Roskilde, Denmark \\ ${ }^{b}$ Institut für Angewandte Materialien, Werkstoffe der Elektrotechnik, Karlsruher Institut für Technologie (KIT), \\ D-76131 Karlsruhe, Germany
}

\begin{abstract}
Electrochemical reaction kinetics at the electrodes of Solid Oxide Cells (SOCs) were investigated at $700^{\circ} \mathrm{C}$ for two cells with different fuel electrode microstructures as well as on a third cell with a reduced active electrode area. Three fuel mixtures were investigated - hydrogen/steam and model reformate fuels-hydrogen/carbon-dioxide and hydrogen/methane/steam. It was found that the electrode kinetics at the fuel electrode were exactly the same in both reformates. The hydrogen/steam fuel displayed 5-7\% faster kinetics than the reformate fuels. 19\% faster kinetics were recorded for the cell with a finer microstructure. The measured gas conversion impedance was compared with models in literature for both the 16- and the $2 \mathrm{~cm}^{2}$ cells. The continuously stirred tank reactor (CSTR) AC model approximated the overpotential of the smaller cells $\left(2 \mathrm{~cm}^{2}\right)$ with greater accuracy in the current density range $0-0.5 \mathrm{~A} / \mathrm{cm}^{2}$ while the plug flow reactor (PFR) model although derived for the case of zero DC bias predicted the $16 \mathrm{~cm}^{2}$ cell ASR better than the zero bias CSTR model. Furthermore, the gas conversion impedance in the hydrogen/steam fuel split into two processes with opposing temperature behavior in the reformate fuels. By using a $87.5 \%$ smaller active electrode area the gas conversion impedance was diminished in the hydrogen/steam fuel at (the same absolute) high fuel flow rates. In both reformates, the second and third lowest frequency processes merged into a single process as the gas conversion was reduced. The SOC with finer electrode microstructure displayed improved kinetics.

(C) The Author(s) 2016. Published by ECS. This is an open access article distributed under the terms of the Creative Commons Attribution 4.0 License (CC BY, http://creativecommons.org/licenses/by/4.0/), which permits unrestricted reuse of the work in any medium, provided the original work is properly cited. [DOI: 10.1149/2.1201613jes] All rights reserved.

(cc) BY
\end{abstract}

Manuscript submitted August 2, 2016; revised manuscript received October 5, 2016. Published October 14, 2016. This was Paper 40 presented at the Cancun, Mexico, Meeting of the Society, October 5-9, 2014.

The Solid Oxide Cell (SOC) is an energy conversion technology that, when included in the energy mix, can alleviate some of the challenges faced by wind and solar technologies such as intermittent availability. Furthermore, whereas utility scale wind and solar generation generally occurs at sites far away from the cities and requires large open areas, the SOC technology is more compact both for utility scale and distributed generation and can be generated much closer to where it is needed, avoiding losses associated with power transport. When operated as a Solid Oxide Fuel Cell (SOFC) the SOC converts the chemical energy in hydrogen as well as hydrocarbon fuels directly into electricity (Eq. 1). The same SOC can also be operated in a reverse mode as a Solid Oxide Electrolysis Cell (SOEC) in which case hydrogen or syngas is produced by electrochemical reduction of steam or steam/carbon-dioxide mixture respectively (Eq. 2).

$$
\begin{aligned}
& \mathrm{H}_{2}+\frac{1}{2} \mathrm{O}_{2} \rightarrow \mathrm{H}_{2} \mathrm{O}+\text { electric energy }+ \text { heat } \\
& \mathrm{H}_{2} \mathrm{O}+\text { electric energy }+ \text { heat } \rightarrow \mathrm{H}_{2}+\frac{1}{2} \mathrm{O}_{2}
\end{aligned}
$$

An SOFC can be operated either for continuous power generation or for power balancing during peak demand. Systems have been demonstrated from less than $1 \mathrm{~kW}$ to several $100 \mathrm{~kW}$ of electricity and corresponding amounts of heat. ${ }^{1}$ Thus the SOFC delivers both electrical power but also high grade thermal power, i.e. combined heat and power systems (CHP) and the operation point and system size can be tailored to suit the desired heat-to-power ratio. The heat can either be used to operate gas or steam turbines or used directly for district heating.

The most commonly considered fuel for any kind of fuel cell is hydrogen; however, the high operation temperatures of SOCs between 600 - and $900^{\circ} \mathrm{C}$ increase the tolerance to impurities and carbon monoxide as well as reduce the need for noble metal catalysts. The SOC is unique (except maybe MCFC) with the $\mathrm{O}^{2-}$ ion as carrier in being able to oxidize $\mathrm{CO}$ and perhaps hydrocarbons directly. These considerations mean the portfolio of fuels is increased to natural gas, methane, methanol, landfill and other hydrocarbons. The maximum electrical efficiency of an SOFC is not limited by the Carnot efficiency but by electrochemical and ohmic losses at the chosen operation point. As such through continual optimization of the cells, stacks and systems through R\&D high electrical net efficiencies ${ }^{c}$ of 45 to $60 \%$ have been achieved at commercial product level. ${ }^{2-4}$ With pressurized systems efficiencies $>60 \%$ (HHV) by 2030 are expected. ${ }^{5}$ Furthermore, due to the absence of open flames the emissions from SOFCs are much less than those from comparable sized conventional power plants. ${ }^{6,7}$

Optimization and commercialization of SOFC technology requires a sound understanding of the mechanisms involved as well as factors that affect performance and stability. Such mechanisms include charge transfer at the reaction sites inside the porous electrodes, electronic and ionic charge transport and gas transport related processes as gasdiffusion and conversion. The main factors influencing these are operating temperature, gas composition, fuel utilization and current load as well as material and microstructural parameters of the cell. These factors increase the complexity of the systems and render deconvolution and analytical description of the involved mechanisms very challenging - especially if their macroscopic trends and fundamental electrochemistry are to be accommodated.

In case of reformate fuels the complexity is further increased by heterogeneous catalysis such as steam reforming (cf. Eq. 3) and the concurrent water gas shift reaction (cf. Eq. 4). Depending on reactant gas composition and operation point the reverse reactions to Equations 3 and 4 can be favored and their associated opposite thermal natures (exothermic methanation in Eq. 3 and endothermic reverse water gas shift in Eq. 4) further increase the complexity of the kinetics.

$$
\begin{gathered}
\mathrm{CH}_{4}+\mathrm{H}_{2} \mathrm{O} \leftrightarrow \mathrm{CO}+3 \mathrm{H}_{2} \Delta_{R} H^{0}=+206 \mathrm{~kJ} \mathrm{~mol}^{-1} \\
\mathrm{CO}+\mathrm{H}_{2} \mathrm{O} \leftrightarrow \mathrm{CO}_{2}+\mathrm{H}_{2} \Delta_{R} H^{0}=-41 \mathrm{~kJ} \mathrm{~mol}^{-1}
\end{gathered}
$$

In literature, the operation of the SOC with $\mathrm{Ni} / \mathrm{YSZ}$ fuel electrodes in reformate fuels has been addressed from diverse angles. 
Timmerman et al. ${ }^{8}$ have investigated and modelled methane reforming kinetics of an SOFC with Ni/YSZ fuel electrode for stationary as well as auxiliary power unit (APU) relevant fuel mixtures. The determined kinetic expression could adequately accommodate methane reforming as well as the reverse (methanation) reactions.

Weber et al. ${ }^{9}$ investigated the possibilities and limitations of operating a state of the art SOFC with $\mathrm{Ni} / \mathrm{YSZ}$ cermet fuel electrode in carbon-based fuels. No significant difference in initial cell performance was observed during operation with dry $\mathrm{H}_{2}, \mathrm{CO}$ or $\mathrm{CH}_{4}$ fuels. Although the cell could be operated for $1000 \mathrm{~h}$ in dry $\mathrm{CH}_{4}$ at $950^{\circ} \mathrm{C}$ without significant problems, the necessity of enough $\mathrm{O}_{2}$ to avoid coking was emphasized.

Leonide et al. $^{10}$ reported a $6-18 \%$ lower power density during biogas operation of an SOFC with a Ni/YSZ cermet fuel electrode as compared to $\mathrm{H}_{2}$ operation. Through electrochemical impedance spectroscopy, Leonide observed an additional process below $2 \mathrm{~Hz}$ in the biogas fuel. This low frequency reformate process is thought to be a coupling of mass transport and water-gas-shift reaction. ${ }^{11,12}$

Current SOFC research is aimed at reducing operation temperature toward and below $700^{\circ} \mathrm{C}$. However steam reforming is thermodynamically more favorable at higher temperatures and low pressures, such that large scale industrial steam reforming is typically carried out above $700{ }^{\circ} \mathrm{C}^{13}$ It is thus necessary to investigate reaction kinetics in different fuels at around $700^{\circ} \mathrm{C}$.

This work is aimed at comparing the kinetic performance of the composite Ni/YSZ electrode in different fuel mixtures. This entails isolating the current density vs. overpotential relations of individual loss mechanisms of the SOC through detailed electrochemical impedance spectroscopy investigations. The influence of microstructure, active electrode area, fuel flow rate and fuel composition are investigated. Attempts to generate analytical descriptions are not made but reserved for future work. An additional major objective is to provide the SOFC community with high quality experimental data that can be used for diverse modeling validations.

\section{Experimental}

Cell system.-The investigated single cells were anode supported cells (ASCs) with porous Ni/3YSZ substrates (ca. $0.3 \mathrm{~mm}$ ), porous Ni/8YSZ anodes (ca. $10 \mu \mathrm{m}$ ), dense 8YSZ electrolytes (ca. $5 \mu \mathrm{m}$ ), dense $\mathrm{Ce}_{0.9} \mathrm{Gd}_{0.1} \mathrm{O}_{2-\delta}$ buffer layers (ca. $1 \mu \mathrm{m}$ ) and porous $\mathrm{La}_{0.6} \mathrm{Sr}_{0.4} \mathrm{CoO}_{3-\delta} / \mathrm{Ce}_{0.9} \mathrm{Gd}_{0.1} \mathrm{O}_{2-\delta}$ cathodes (ca. $30 \mu \mathrm{m}$ ). Details about the cells and the manufacturing procedure can be found in literature. ${ }^{14}$ Cells A and B (cf. Figure 1 (i and iii)) each had a $4 \times 4 \mathrm{~cm}^{2}$ active

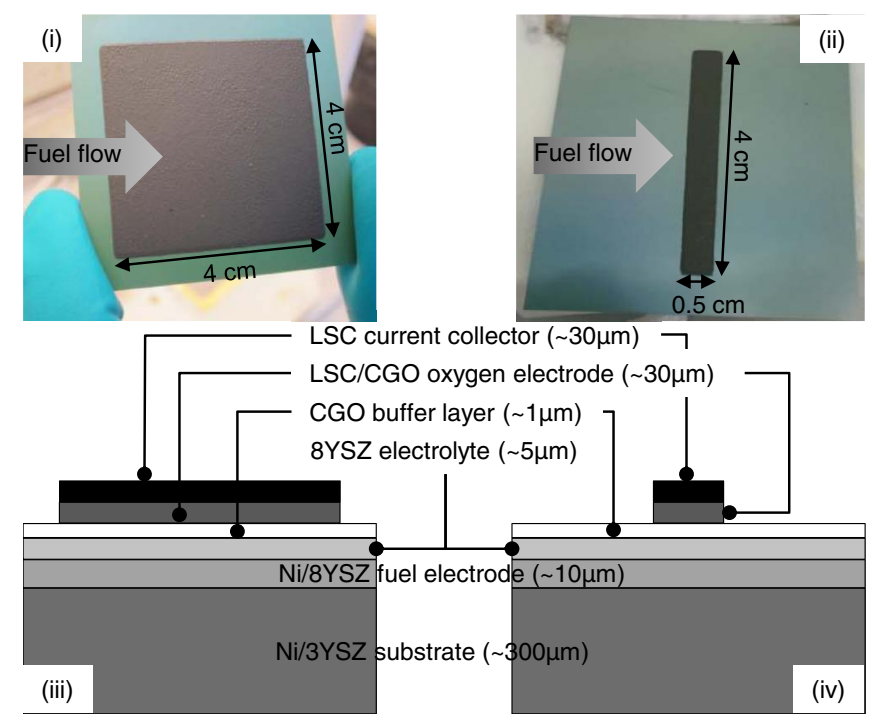

Figure 1. Cell Geometry: (i) top view of cells A and B, (ii) top view of cell $\mathrm{C}$, (iii) schematic of cross-sections of cells A and B (not to scale) and (iv) schematic of cross-section of cell C.
Table I. Investigated Cells.

Cell ID Active Electrode Area $\left[\mathrm{cm}^{2}\right] \quad$ Fuel Electrode Microstructure

$\begin{array}{ccc}\mathrm{A} & 16 & \text { Reference } \\ \mathrm{B} & 16 & \text { Finer } \\ \mathrm{C} & 2 & \text { Finer }\end{array}$

electrode area. Considering Cell A as reference cell, Cell B differed in that it had a finer Ni/8YSZ fuel electrode microstructure. ${ }^{15}$ Unlike cells A and B, Cell C (cf. Figure 1 (ii and iv)) had a $4 \times 0.5 \mathrm{~cm}^{2}$ strip-shaped geometry oxygen electrode screen-printed at the center, resulting in a cell with $2 \mathrm{~cm}^{2}$ active electrode area. This means that at the fuel electrode the fuel flowed across the $4 \mathrm{~cm}$ edge parallel to the $0.5 \mathrm{~cm}$ edge.

The microstructure of Cell $\mathrm{C}$ though was quantitatively similar to that of Cell B. The differences are summarized in Table I.

Operation conditions. - The majority of the investigations were carried out at $700^{\circ} \mathrm{C}$ in three fuel mixtures - Fuel I, Fuel II and Fuel III. Fuel I was composed solely of hydrogen and steam in an 80:20\% ratio at the inlet. At $700^{\circ} \mathrm{C}$ this corresponded to an open circuit voltage (OCV) of $1030 \mathrm{mV}$. The second fuel, Fuel II had hydrogen and carbon dioxide in the ratio $81: 19 \%$ at the inlet. The third fuel, Fuel III was a methane-based reformate fuel with hydrogen, methane and steam with mole fractions of 10-, 30- and $60 \%$ respectively. The choice of the component mole fractions, aided by thermodynamic calculations, was such that the equilibrium composition of the reformates was the same $-64 \% \mathrm{H}_{2}, 16 \% \mathrm{H}_{2} \mathrm{O}, 5 \% \mathrm{CO}_{2}, 13 \% \mathrm{CO}$ and $2 \% \mathrm{CH}_{4}$. It was further ensured that at equilibrium, the $\mathrm{OCV}$ of the reformate fuels was also $1030 \mathrm{mV}$ at $700^{\circ} \mathrm{C}$. The required steam content was obtained by allowing appropriate amounts of oxygen and hydrogen to react in a combustion chamber close to the cell inlet. Details of the test facilities have been described elsewhere. ${ }^{16}$ The operation conditions are summarized in Table II.

Fuel I was obtained by flowing $7 \mathrm{~L} / \mathrm{h}$ of hydrogen and $0.7 \mathrm{~L} / \mathrm{h}$ of oxygen. To obtain Fuel II $5.6 \mathrm{~L} / \mathrm{h}$ of hydrogen and $1.3 \mathrm{~L} / \mathrm{h}$ of carbon dioxide were supplied to the cell. Fuel III was obtained by supplying $3.0 \mathrm{~L} / \mathrm{h}$ of hydrogen, $1.29 \mathrm{~L} / \mathrm{h}$ of oxygen and $1.29 \mathrm{~L} / \mathrm{h}$ of methane. With these flows, the fuel utilization at the investigated maximum current density of $0.5 \mathrm{~A} / \mathrm{cm}^{2}$ was $60 \%$ for the $16 \mathrm{~cm}^{2}$ cells (A, B) and $7.5 \%$ for the $2 \mathrm{~cm}^{2}$ cell (C). The fuel utilization and current density range were chosen to emulate practical conditions. In all cases, the oxygen electrode was supplied with $40 \mathrm{~L} / \mathrm{h}$ of air. All flow rates are reported with respect to a temperature of $273.15 \mathrm{~K}$ and a pressure of 1 atmosphere.

Characterization and data acquisition.-Once the appropriate fuel composition was set and enough time for system relaxation was given (30 minutes), the current density was increased stepwise from $\mathrm{OCV}$ to the maximum current density of $0.5 \mathrm{~A} / \mathrm{cm}^{2}$. At each current density step a waiting time of 30 minutes was allowed for relaxation

Table II. Inlet compositions of investigated fuel mixtures as well as the equilibrium concentrations of the reformate fuels at $700^{\circ} \mathrm{C}$. Units: atm.

Inlet

\begin{tabular}{ccccc}
\cline { 3 - 5 } Gas [atm] & Fuel I & Fuel II & Fuel III & Equilibrium Composition \\
\cline { 2 - 5 } & 0.8 & 0.81 & 0.1 & 0.64 \\
$\mathrm{H}_{2}$ & 0.2 & - & 0.6 & 0.16 \\
$\mathrm{H}_{2} \mathrm{O}$ & - & 0.19 & - & 0.05 \\
$\mathrm{CO}_{2}$ & - & - & - & 0.13 \\
$\mathrm{CO}$ & - & - & 0.3 & 0.02 \\
$\mathrm{CH}_{4}$ & & & &
\end{tabular}




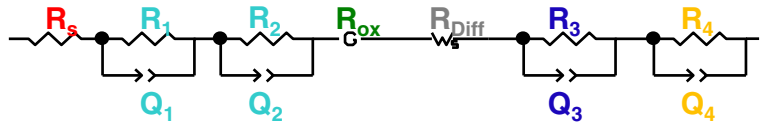

Figure 2. Equivalent electric circuit model used to quantify the ASRs for EIS spectra in reformate operation.

and then an impedance spectrum was recorded in the frequency range $96.850 \mathrm{kHz}$ to $30 \mathrm{mHz}$ using a Solartron 1260 FRA. With a $3 \mathrm{~V}$ root mean square value (rms) voltage signal, the output excitation current signal was $60 \mathrm{~mA} \mathrm{rms} \mathrm{(shunt} \mathrm{resistance} \mathrm{of} 50 \Omega$ ). From $0.5 \mathrm{~A} / \mathrm{cm}^{2}$ the cell was brought back to OCV, a control spectrum recorded and then a current density - voltage characteristic recorded for future validation of the calculations. To exclude contributions from the test set-up, the recorded spectra were corrected with a short-circuit measurement and lead inductance was removed through a procedure utilizing the Kramers-Kronig relations. ${ }^{17,18}$ This procedure involves comparing the imaginary impedance generated from the measured real impedance, with the measured imaginary impedance, and the difference between these is used to determine the inductance.

Equivalent circuit model.-To isolate and quantify the ASR contributions of the involved processes, an adequate equivalent circuit model (ECM) was fitted to the recorded impedance spectra using complex non-linear least squares (CNLS) minimization. A model M0 for anode supported SOFCs described in previous work ${ }^{19}$ was used to quantify spectra recorded in $\mathrm{H}_{2} / \mathrm{H}_{2} \mathrm{O}$ fuel. This model had to be extended with an RQ-element to accommodate gas conversion, ${ }^{20}$ which was negligibly small (and thus not considered) in the system in Reference 19. Also, due to the high air flow rate at the cathode and the overall cathode thickness of $<60 \mu \mathrm{m}$ gas diffusion at the oxygen electrode was neglected. For spectra recorded under reformate operation the model M1 was used, obtained by extending M0 with another RQ-element to describe the extra low frequency process present in reformate fuel spectra. ${ }^{11,21,22}$ The ECM model (cf. Figure 2) thus comprised an ohmic resistance to model the ohmic losses across the cell (predominantly caused by ionic transport across the electrolyte), two RQ-elements to quantify the fuel electrode electrochemical oxidation and its coupling with the ionic transport in the fuel electrode, a Gerischer element to model surface exchange and oxygen ion bulk diffusion in the oxygen electrode, a Warburg element for gas phase diffusion in the substrate, an RQ-element for fuel electrode gas conversion and finally an RQelement for the extra low frequency process in reformate fuels.

Pre-identification of the processes prior to the CNLS fitting as well as fit quality validation by simulation of fitted processes was done by calculating the distribution of relaxation times (DRT). ${ }^{23}$ Prior to the fitting and calculation of DRTs, adequate data quality was assured by checking the compliance of the data with Kramers-Kronig (KK) transforms ${ }^{17,18}$ and the fit residuals and goodness of fit values were also carefully considered. All CNLS fits, DRT- and KK-transforms as well as simulations were done using the software RAVDAV. ${ }^{24}$

As can be seen from Figure 3 the data and fit quality are very good with residuals well within the $\pm 0.5 \%$ range. The evenly fluctuating distribution of the residuals about the zero-line further stresses the absence of systematic errors.

Calculation of current density vs. overpotential relations.-The total measured impedance at each current corresponds to the slope of the current-voltage curve at the given current. Thus, by integration of the curve defined by the determined slopes it is possible to reconstruct the current-voltage curve. Through integration of the ASRs obtained from the CNLS fit (cf. Figure $4 \mathrm{~b}$ ) with current density the overpotential contributions of the individual processes could be determined (cf. Figure 4c). A cumulative deduction of the obtained overpotentials from the OCV, (starting with gas conversion and ending with oxygen electrode contribution) results in a simulation of the $\mathrm{C} / \mathrm{V}$ - characteristic. This can be compared with the measured characteristic to validate the procedure and as displayed in Figure $4 \mathrm{~d}$ the simulated curve perfectly overlays the measured curve, thereby validating the procedure. It should be mentioned that for this approach we do not apply a detailed electrochemical model as was done in literature ${ }^{25}$ to calculate losses and the CV-characteristic.

Besides determining the overpotential contributions of individual cell processes, an important benefit of the procedure described in Figure 4 is that the technique can be applied to define a safe operation window for the cell (electrode) at the chosen operation point. This is shown in Figure 5 based on the operation point of $700^{\circ} \mathrm{C}$, air to the oxygen electrode and Fuel I $\left(80 / 20 \% \mathrm{H}_{2} / \mathrm{H}_{2} \mathrm{O}\right)$ to the fuel electrode. The following information can be obtained from Figure 5:

i. The open circuit potential (OCP) of LSC/CGO in air versus a $\mathrm{Pt} / \mathrm{O}_{2}(0.21 \mathrm{~atm})(=0 \mathrm{mV})$

ii. The evolution of the LSC/CGO oxygen electrode polarization in the investigated current density range. This curve is obtained by deducting the overpotential contribution of the oxygen electrode (cf. Figure 4c) from the Pt/(LSC/CGO) in air value of $0 \mathrm{~V}$. The LSC/CGO oxygen electrode shows a very low polarization of -6 $\mathrm{mV}$ at $0.5 \mathrm{~A} / \mathrm{cm}^{2}$

iii. The $\mathrm{Ni} / \mathrm{NiO}$ redox pair potential versus a $\mathrm{Pt} / \mathrm{O}_{2}(0.21 \mathrm{~atm})$ reference electrode of $-764 \mathrm{mV}$ at $700^{\circ} \mathrm{C}$

iv. The evolution of the Ni/YSZ fuel electrode polarization in the investigated current density range. This curve is obtained by adding the overpotential contributions of the fuel electrode processes in Figure 4c (gas conversion, substrate diffusion and electrochemical oxidation and ionic transport in the fuel electrode) to the OCP of the Ni/YSZ electrode in Fuel I at $700^{\circ} \mathrm{C}$

v. The open circuit potential of the $\mathrm{Ni}$ (or Ni/YSZ) electrode in Fuel $I \mathrm{vs} \mathrm{Pt} / \mathrm{O}_{2}(0.21 \mathrm{~atm})$ reference electrode at $700^{\circ} \mathrm{C}$ of $-1030 \mathrm{mV}$.

As can be deduced from Figure 5, the change in the potential of the oxygen electrode in the current density range 0 to $+0.5 \mathrm{~A} / \mathrm{cm}^{2}$ is negligible as expected based on the corresponding ovepotential calculated in Figure 4c. On the other hand, the fuel electrode displays a significantly larger change in potential. However, and most importantly, the fuel electrode potential increasing from $-1030 \mathrm{mV}$ at OCV reaches a maximum value around $-911 \mathrm{mV}$ at $+0.5 \mathrm{~A} / \mathrm{cm}^{2}$; since the oxidation of $\mathrm{Ni}$ to $\mathrm{NiO}$ does not start until $-764 \mathrm{mV}$ is reached the result implies that under the investigated conditions, the SOC is being operated in a safe window. A similar check was performed for all applied operating conditions to ensure that a failure or enhanced degradation due to reoxidation can be excluded. It should be noted that the $-911 \mathrm{mV}$ value is the average fuel electrode potential. The potential increases (becomes less negative) along the fuel flow channel as fuel is oxidized. Therefore, the local fuel electrode potential at the outlet is somewhat closer to the $\mathrm{Ni} / \mathrm{NiO}$ threshold, but it is not expected to exceed the threshold based on what is known about three-dimensional potential profiles

\section{Results and Discussion}

Evolution of individual processes under load.-By calculating the DRTs from impedance spectra recorded at all current densities a qualitative appreciation of the behavior of individual processes under current load could be obtained. These are displayed in Figure 6 for cells A, B and C and the three fuel mixtures, Fuel I, Fuel II and Fuel III.

From Figure 6 and based on the frequency range of the processes as shown in Figure 3f, as well as the fact that the area enclosed by a DRT peak corresponds to the ASR of the dynamic process, ${ }^{19,23,26}$ the following observations can be made:

i. The polarization resistance related to gas conversion (ca. $\mathrm{f}=1$ $\mathrm{Hz}$ ) does not depend on the microstructure of the fuel electrode (cf. (a_i) vs. (b_i)) but only on the active electrode geometric area (cf. (a_i) and (b_i) vs. (c_i)). This is consistent since a reduced active electrode area (at constant unchanged fuel flow 
(a) EIS Spectrum

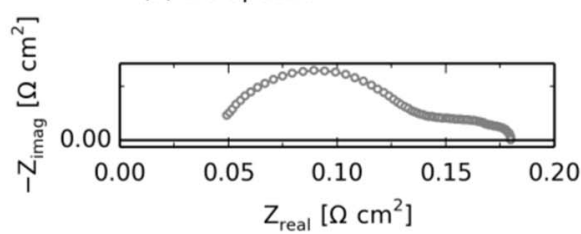

(c) CNLS Fit
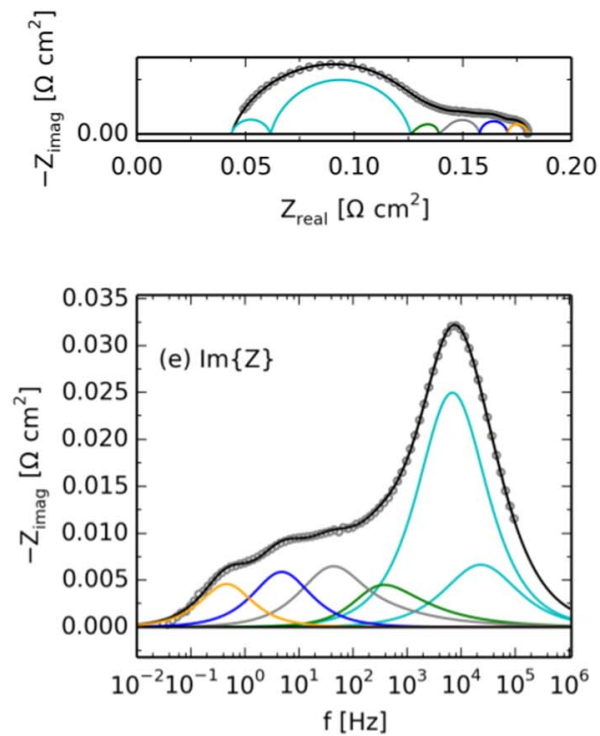

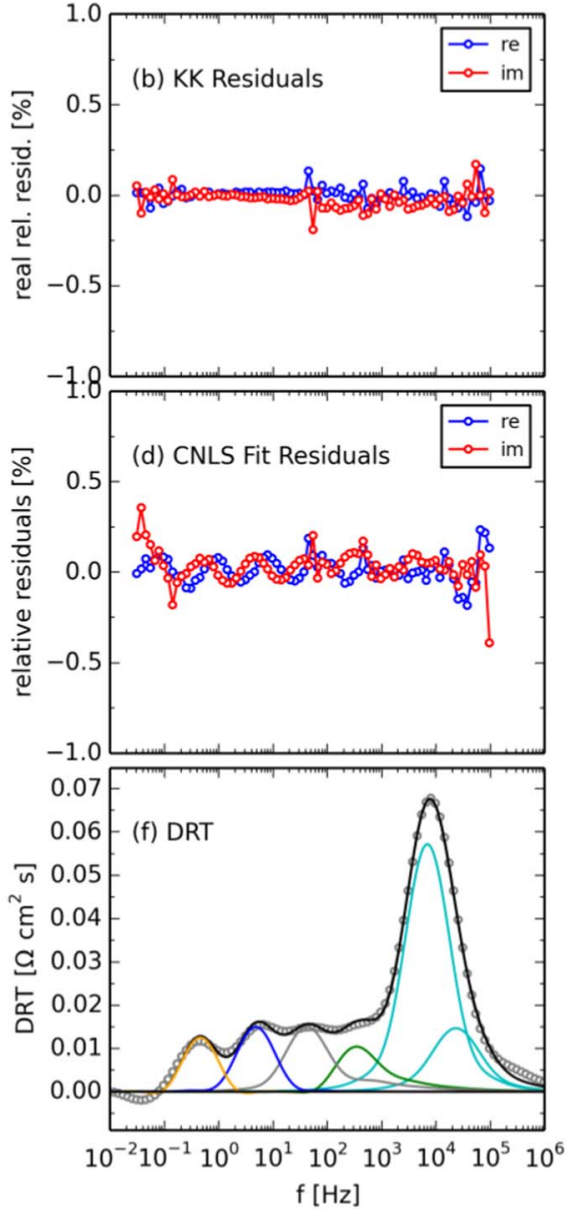

$\rightarrow$ Data $-\mathrm{fit}$ - RQ1_FE_1

Figure 3. (a) Impedance spectrum of Cell $\mathrm{C}$ at $700^{\circ} \mathrm{C}$ at a current density $+0.5 \mathrm{~A} / \mathrm{cm}^{2}$ in reformate fuel Fuel II, (b) the corresponding KK-test residuals, (c) the CNLS fit, with Boukamp goodness of fit $\chi^{2}=1.4 \mathrm{E}-4$, (d) corresponding CNLS fit residuals, (e) imaginary part of spectrum and fit, (f) DRT of spectrum and simulation of fit processes.

rate) results in reduced fuel utilization leading to a decrease in the associated conversion ASR.

ii. The gas conversion ASR decreases with increasing current density to a minimum value then starts increasing at around 0.5 $\mathrm{A} / \mathrm{cm}^{2}$. With an inlet average $\mathrm{pH}_{2} \mathrm{O}$ of $20 \%$, the steam partial pressure increases with increasing current density and as such the gas conversion ASR is expected to decrease going through a minimum at $50 \%$ average $\mathrm{pH}_{2} \mathrm{O}$ over the cell ${ }^{27}$ (cf. Equation 9). This coincides with a current density between 0.4 and $0.5 \mathrm{~A} / \mathrm{cm}^{2}$ in Figures 6a_i and 6b_i.

iii. The gas conversion peak in Fuel I splits into two low frequency peaks in reformate fuels (cf. (a_i) vs (a_ii) or (b_i) vs. (b_ii) and (b_iii)), overlapping to a single peak at $0.5 \mathrm{~A} / \mathrm{cm}^{2}$.

iv. The two low frequency processes in the reformate fuels are very similar in magnitude and display similar behavior with current density (cf. (b_ii) vs (b_iii) for $\mathrm{f}<10 \mathrm{~Hz}$ ).

v. Gas phase diffusion ASR in the substrate (cf. $10 \mathrm{~Hz}<\mathrm{f}<$ $100 \mathrm{~Hz}$ in (a_i)) decreases with increasing current density in the investigated range.

vi. The ASR related to the surface exchange and bulk ion transport at the oxygen electrode is very small and overlaps with the fuel electrode process rendering accurate deconvolution difficult.

vii. The ASR related to electrochemical oxidation and ionic transport at the fuel electrode (cf. $\mathrm{f}>1 \mathrm{kHz}$ ) decreases with increasing current density. Unlike the gas conversion peak (cf. f $<10 \mathrm{~Hz}$ in $a \_i$ or $\left.b \_i\right)$ that maintain the peak frequency, the electrochem- ical reaction peaks are drifting toward higher frequencies with increasing current density.

viii. A finer fuel electrode microstructure decreases the ASR related to electrochemical oxidation and ionic transport in the fuel electrode (cf. Cell A vs. Cell B for $\mathrm{f}>1 \mathrm{kHz}$ and all fuel mixtures)

ix. Active electrode area has negligible impact on electrochemical oxidation and ionic transport at the fuel electrode. (cf. Cell B vs. Cell $\mathrm{C}$ for $\mathrm{f}>1 \mathrm{kHz}$ and all fuel mixtures)

These points will be discussed in the next sections together with the calculated corresponding current density vs. overpotential curves.

Current density vs. overpotential relations of individual processes.-As mentioned earlier, by integrating the ASR vs. current density curves of the individual processes obtained from the CNLS fit, the corresponding overpotential vs. current density contributions can be determined, as shown in Figure 7.

Reference case.-If Cell A, fuel mixture Fuel I i.e. Figure 7(a_i) and current density $0.4 \mathrm{~A} / \mathrm{cm}^{2}$ (if not otherwise stated) are considered the reference then the following claims can be made about the investigated cell system at $700^{\circ} \mathrm{C}$ :

- The fuel electrode electrochemical reactions (charge transfer and ionic transport and gas diffusion in the anode functional layer ${ }^{25,28}$ ) make the largest overpotential contributions (ca. 39\% of total over- 
(a)
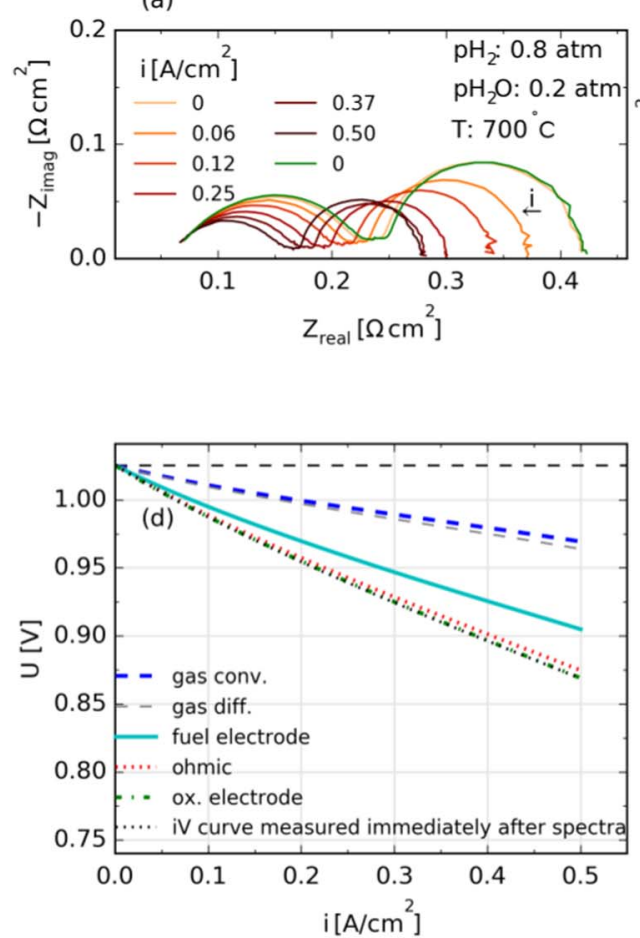

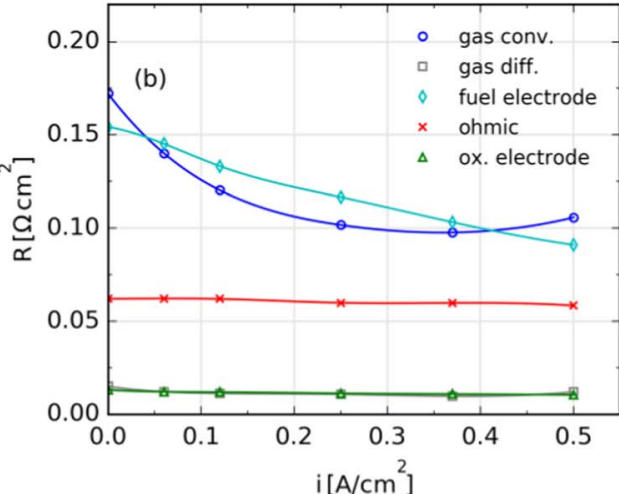

$\mathrm{i}\left[\mathrm{A} / \mathrm{cm}^{2}\right]$

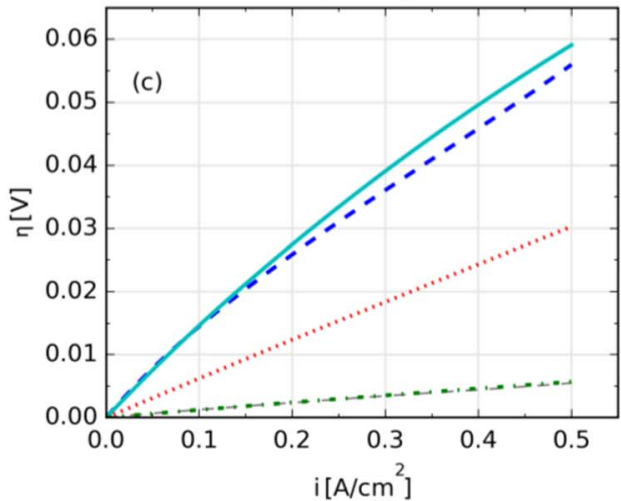

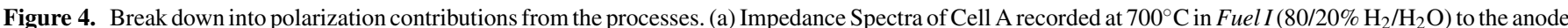

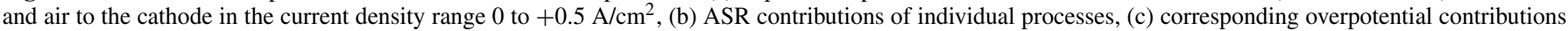

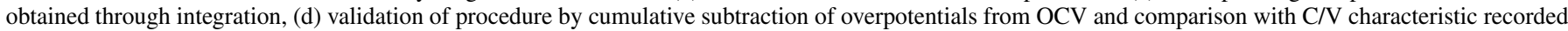
after return to OCV and OCV control spectrum.

potential drop). This implies that engineering efforts to optimize cell performance of the investigated cells should focus on the fuel electrode.

- The oxygen electrode accounts for the smallest share (ca. 4\%) of the total potential drop.

- Gas conversion resistance has the second largest overpotential contribution. (ca. $35 \%$ )

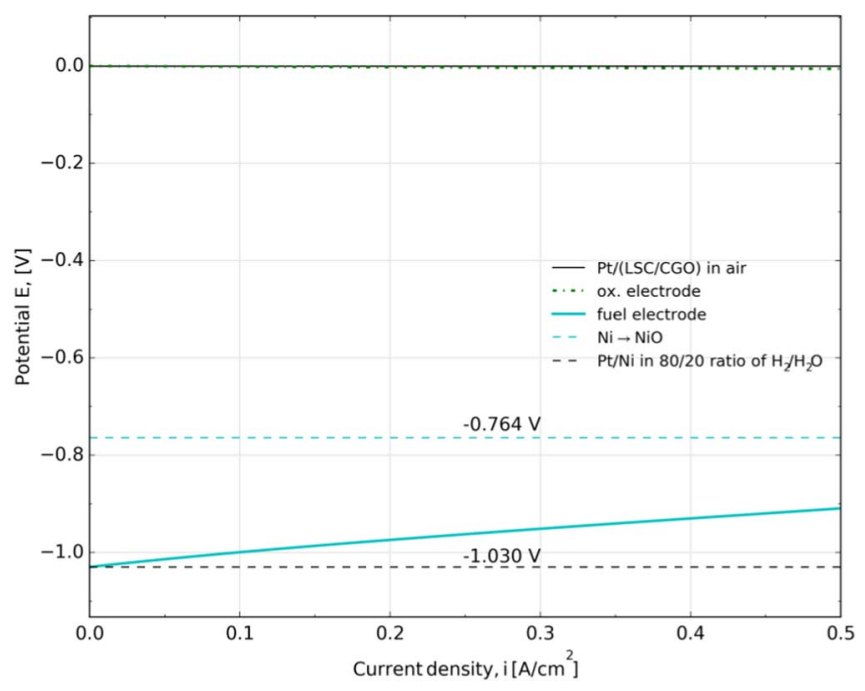

Figure 5. Evolution of electrode potentials with current density for the fuel and oxygen electrodes, calculated from impedance spectra recorded at $700^{\circ} \mathrm{C}$ in the current load range $0-0.5 \mathrm{~A} / \mathrm{cm}^{2}$ with Fuel I $\left(80 / 20 \% \mathrm{H}_{2} / \mathrm{H}_{2} \mathrm{O}\right)$ supplied to the anode and air supplied to the cathode.
- The voltage drop due to ohmic losses across the electrolyte accounts for $20 \%$ of the total voltage drop and thus half as much as in the fuel electrode.

- Gas phase diffusion equally contributes the least (ca. 4\%) to the voltage drop.

From a global perspective, it can be deduced from Figure 7(a_i) that in the current density range 0 to $0.5 \mathrm{~A} / \mathrm{cm}^{2}$ gas diffusion displays a linear relationship between current density and overpotential. ${ }^{27}$ This suggests that the change of gas diffusion ASR in the investigated range is negligible ${ }^{29}$ and will be addressed in more detail in a later section. The voltage drop across the electrolyte displays a linear relationship between current density and overpotential. This suggests that the impact of joule heating (for $\mathrm{j}<0.5 \mathrm{~A} / \mathrm{cm}^{2} \mathrm{ca} .<2^{\circ} \mathrm{C}$ increase of temperature ${ }^{30}$ ) in the investigated current density range is not enough to visibly curb the overpotential trend of the electrolyte resistance. The electrochemical reactions at the fuel electrodes on the other hand show non-linear current density vs. overpotential relations ${ }^{30}$ at $700^{\circ} \mathrm{C}^{\mathrm{d}}$. The nonlinearity is such that the overpotential deviates to "smaller" values with increasing current density (decrease in slope). Independent of the nature of the pure kinetically defined course, the curbing away from linearity may partly be attributed to:

a. Increasing temperature under current load as a result of joule heating across the electrolyte

b. Increasing temperature due to the exothermic hydrogen oxidation at the fuel electrode.

c. At the fuel electrode, the increasing steam content at the triple phase boundaries (TPB) with increasing current densities results in increased electrochemical reaction rate ref,30 $^{25}$ and thus reduced ASR.

${ }^{\mathrm{d}}$ The trend of the oxygen electrode cannot be unambiguously discussed due to the very small contribution. 


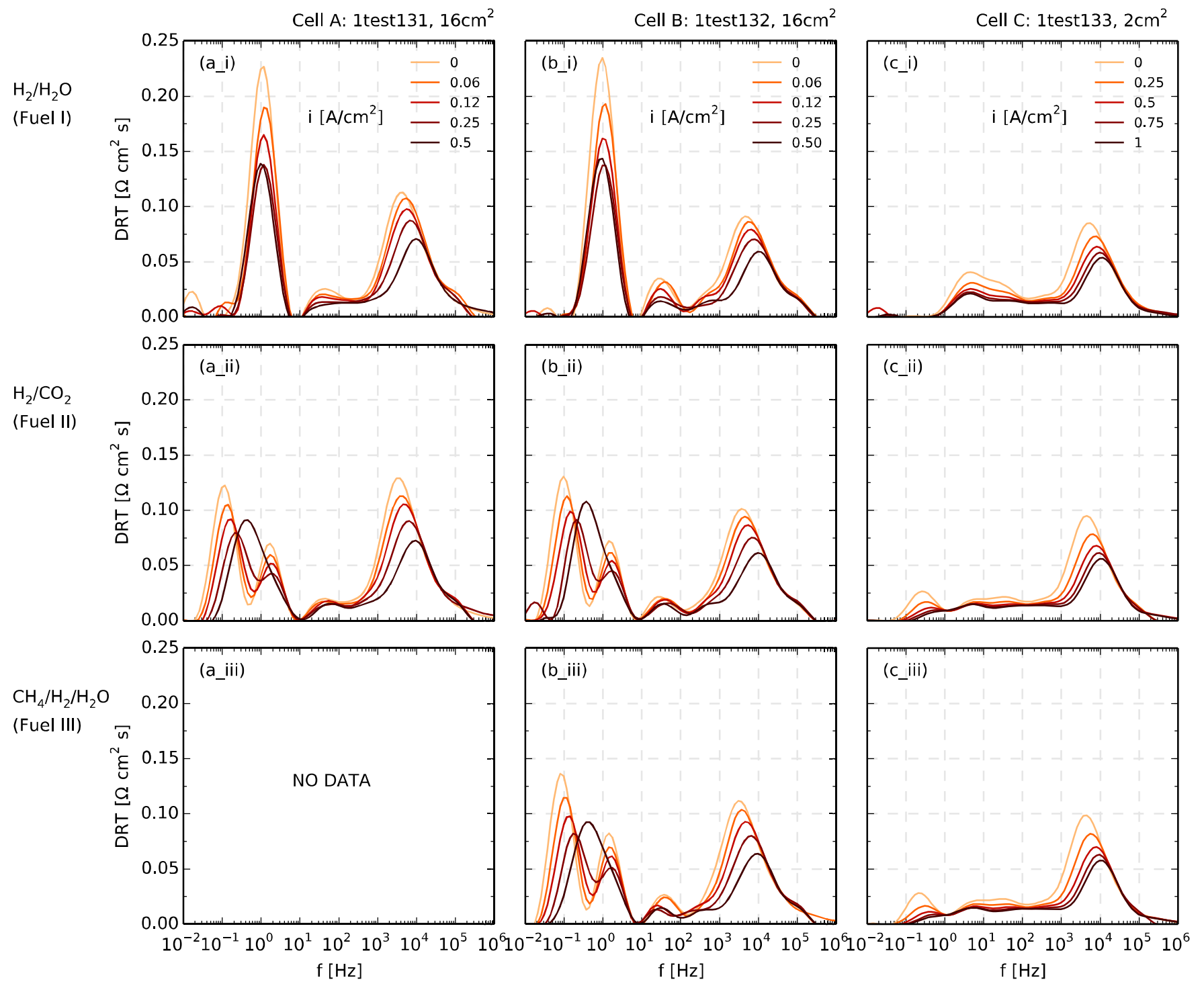

Figure 6. DRTs of cells A, B and C calculated from impedance spectra recorded during operation with the three fuels Fuel I, Fuel II and Fuel III at $700^{\circ} \mathrm{C}$ showing the evolution of ASRs of individual processes from OCV to $+0.5 \mathrm{~A} / \mathrm{cm}^{2}$.

At the oxygen electrode the temperature effect related to the electrochemical reactions is endothermic in nature due to dissociation and ionization enthalpies of oxygen molecules and atoms respectively. However major oxygen electrode processes such as surface exchange and bulk ion transport are thermally activated with activation energies for $K^{\delta}$ and $D^{\delta}$ of 1.05 - and $1.26 \mathrm{eV}$ respectively. ${ }^{31}$ As such the decreasing slope at higher current densities thus suggests that the endothermic needs are relatively small and are wholly compensated by joule heating or operation point heat.

Influence of fuel electrode microstructure.-A comparison of the reference cell with Cell B that had a finer fuel electrode microstructure reveals a decrease in the overpotential due to electrochemical fuel oxidation reactions from $49.7 \mathrm{mV}$ to $39.2 \mathrm{mV}$ (i.e. from $39 \%$ to $33 \%$ ). This is consistent with expectation since a finer microstructure is translated into an increase in the amount of electrochemically active TPBs and an effective decrease in ASR or overpotential. The trend is consistent with the DRTs shown in Figure 6. On the contrary, the gas conversion and gas diffusion overpotentials increase slightly from 45.8- to $47.6 \mathrm{mV}$ and from 4.4 - to $7.5 \mathrm{mV}$ (i.e. 35.5 - to $40.2 \%$ and 3.4- to $6.3 \%$ ) respectively. These are small and within error margin, but certainly exclude a decrease in the ASR of the two processes.
The oxygen electrode overpotential as expected is not affected by the change in microstructure of the fuel electrode. The polarization related to ohmic losses decreases from 24.4 - to $20 \mathrm{mV}$ (i.e. from 19 - to $17 \%$ of total polarization). This decrease is not significant and on the contrary indicates good reproducibility of the electrode manufacturing, and characterization procedure at DTU Energy.

Influence of fuel mixture.-By comparing operation in Fuel I and Fuel II i.e. Figures 7(a_i) vs. 7(a_ii) or 7(b_i) vs. 7(b_ii) a drastic reduction in the gas conversion related overpotential can be observed. At $0.4 \mathrm{~A} / \mathrm{cm}^{2}$ the change in Cell A is from $45.8 \mathrm{mV}$ in Fuel I to $17.4 \mathrm{mV}$ in Fuel II (i.e. from 35 - to $14 \%$ of total potential drop) and in Cell B from $47.6 \mathrm{mV}$ in Fuel I to $18.5 \mathrm{mV}$ in Fuel II (i.e. from 40 to 16\%). In the reformate fuel Fuel II of Cell A the extra process at ca. $0.1 \mathrm{~Hz}$ in Figure 6 (cf. process labeled Ref. in Figure 7) appears and accounts for $23.7 \mathrm{mV}(19 \%)$ of the total voltage drop. In Cell B the process accounts for $24 \mathrm{mV}(21 \%)$ in both Fuel II and Fuel III. As would be expected, no significant change is observed in the overpotential contribution of the oxygen electrode or electrolyte as a result of change in fuel mixture from $\mathrm{H}_{2} / \mathrm{H}_{2} \mathrm{O}$ to either of the reformate fuels. The change of fuel also does not impact the fuel electrode electrochemical reaction rate significantly. A slight increase 


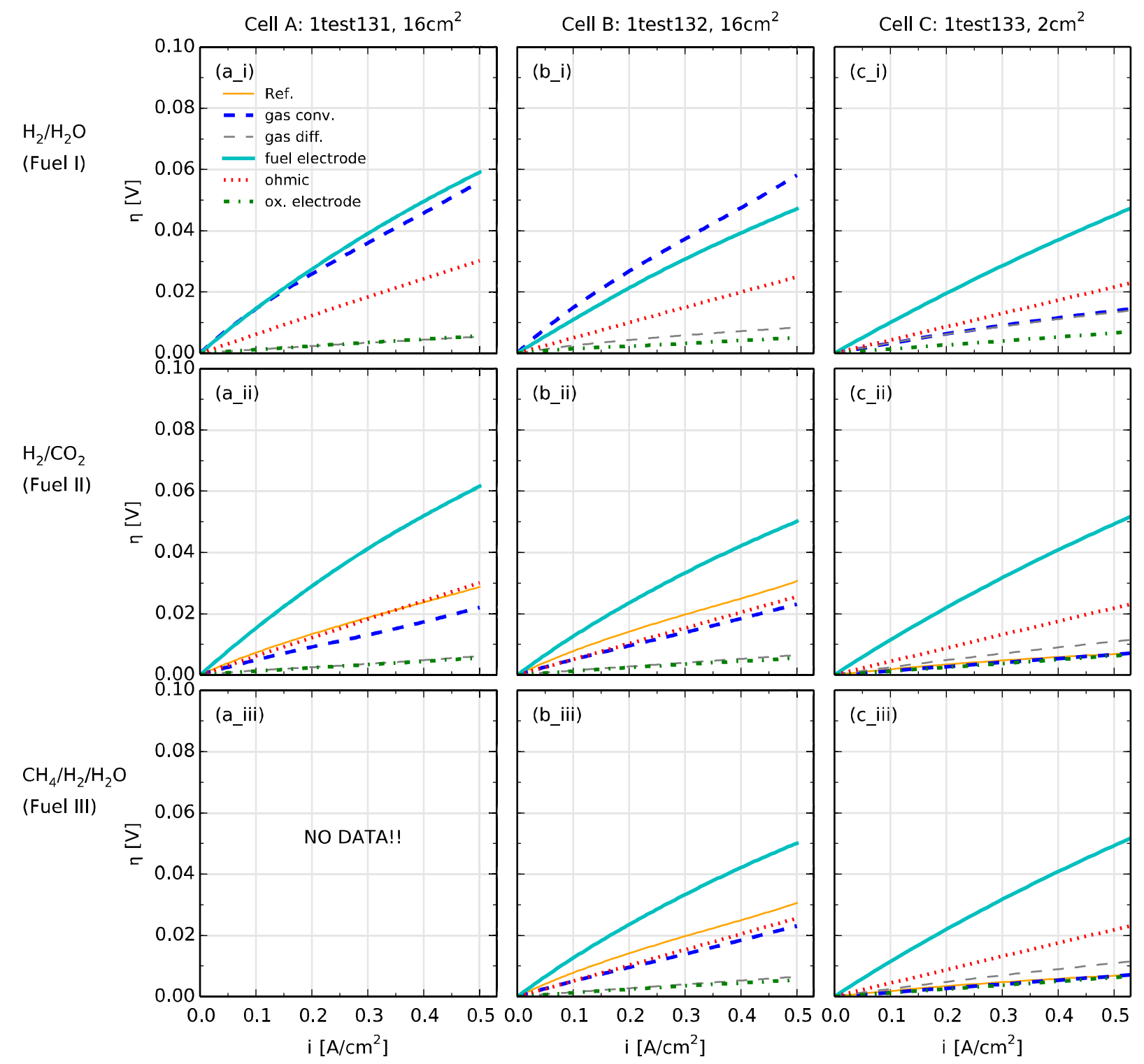

Figure 7. Current density, i vs. overpotential $\eta$ relations for all processes for cells A, B and C in the three fuels Fuel I, Fuel II and Fuel III at $700^{\circ} \mathrm{C}$.

in the overpotential curve of the fuel electrode can be observed when comparing Fuel I and Fuel II of Cell A. At $0.4 \mathrm{~A} / \mathrm{cm}^{2}$ the change is from 49.7 - to $51.9 \mathrm{mV}$ (i.e. from $39 \%$ to $41 \%$ of total overpotential). In Cell B, the change is from 39.2- to $42.2 \mathrm{mV}$ (i.e. from 33- to $36 \%$ ) in both reformate fuels. These findings are consistent with expectation if considered that $\mathrm{H}_{2}$ is preferentially ${ }^{11,32}$ electrochemically oxidized (activation energy, $1.1 \mathrm{eV})^{25}$ against $\mathrm{CO}$ (activation energy, $\left.1.23 \mathrm{eV}\right)^{33}$ which is partly converted through the fast water gas shift reaction in the support and anode layer. As would be expected the different types of gas conversions have different time constants.

Comparison of kinetics at the fuel electrode.-The principal objective of this work was to investigate the kinetics of the fuel electrode in three different fuels consisting of two reformate fuels and a reference hydrogen/steam fuel. Furthermore, it was aimed at investigating the extent to which the microstructure influenced kinetics in these fuels. This information already contained in Figure 7 has been extracted and compared separately in Figure 8 for the cells Cell A and Cell B. Both figures show that under the investigated conditions, the fuel electrode of the Ni/8YSZ electrode displays comparable kinetics in the reformate fuels with overpotentials of $50.1 \mathrm{mV}$ and $51.0 \mathrm{mV}$ in Fuel II and Fuel III respectively in Cell B at $500 \mathrm{~mA} / \mathrm{cm}^{2}$. In hydrogen/steam fuel (Fuell I), Cell B with $47.6 \mathrm{mV}$ at $500 \mathrm{~mA} / \mathrm{cm}^{2}$ displays 5- and $7 \%$ slightly faster kinetics than in Fuel II and Fuel III respectively. A significant improvement in the kinetics is also observed for the cell with a finer microstructure (Cell B), whereby the overpotential at 500 $\mathrm{mA} / \mathrm{cm}^{2}$ of $47.6 \mathrm{mV}$ in Fuel I is with $19.4 \%$ smaller than the $59 \mathrm{mV}$ of Cell A under same conditions.

As mentioned earlier the curves in Figure 8 are accompanied by a temperature and steam content increase with increasing current density. These influences introduce a non-linearity and need to be isolated in an appropriate cell geometry ${ }^{34}$ before any attempts to obtain the analytical description of pure Ni/8YSZ kinetics.

Influence of fuel utilization.-The fuel utilization at a given operation point and current density reveals the amount of the inlet fuel that is actually converted into electric current. For SOC operation, it would be of economic sense to convert as much of the inlet fuel as possible. However for long-term stability of the cell, it is equally important to know how the different processes are affected by high fuel utilization. It is known, that a decrease in fuel utilization leads to an increased cell performance, as fuel conversion and diffusion losses are diminished. ${ }^{35}$ 

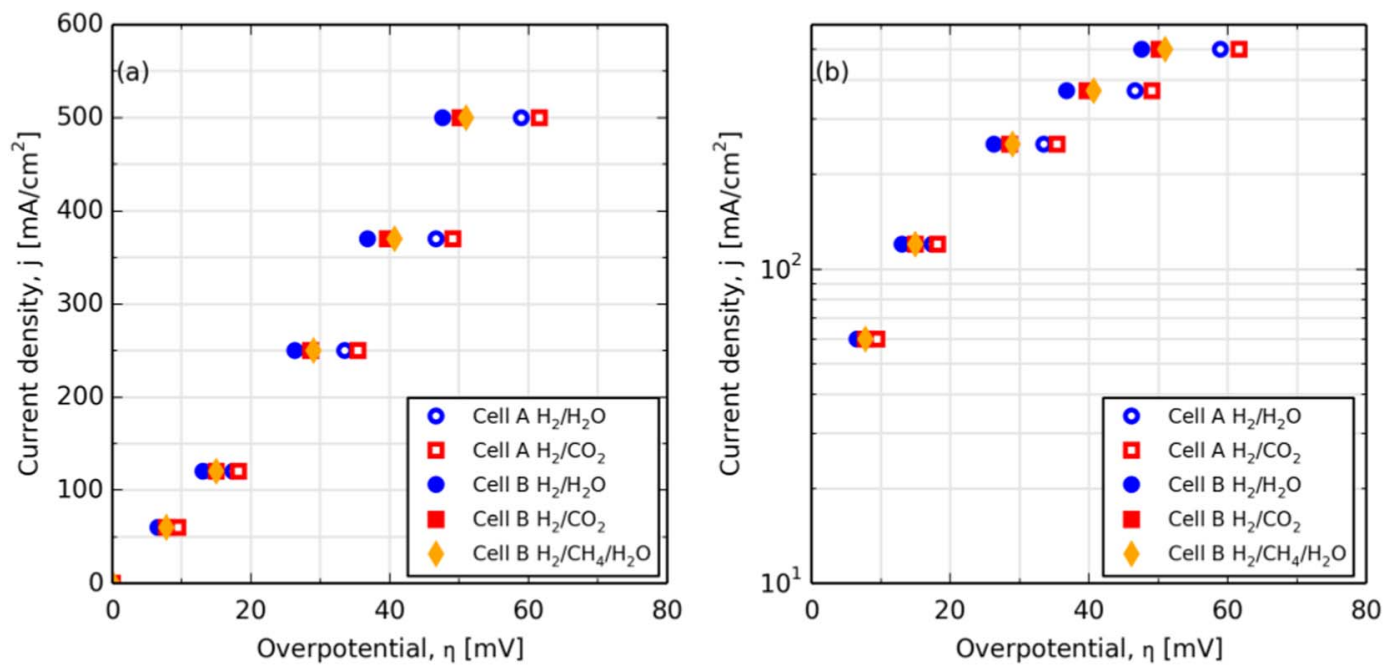

Figure 8. Current density vs. overpotential relations for the three fuels $\mathrm{H}_{2} / \mathrm{H}_{2} \mathrm{O}$ (Fuel I), $\mathrm{H}_{2} / \mathrm{CO}_{2}$ (Fuel II) and $\mathrm{H}_{2} / \mathrm{CH}_{4} / \mathrm{H}_{2} \mathrm{O}\left(\right.$ Fuel III) at $700{ }^{\circ} \mathrm{C}$ for Cell A (reference cell) compared with Cell B (a finer fuel electrode microstructure). Data in the methane-based reformate could not be recorded for Cell A. The OCV in all three fuels was $1030 \mathrm{mV}$ and the fuel utilization at $0.5 \mathrm{~A} / \mathrm{cm}^{2}$ was $60 \%$. Linear representation in (a) and logarithmic scale representation in (b).

The fuel utilization can be varied by changing the active electrode area (at constant gas flow) or by changing the fuel flow rate across the electrode. At much higher flow rates the fuel does not dwell long enough over the electrode for most of it to be electrochemically converted; meanwhile a smaller active electrode area leads to the same result as the fuel mixture crosses the electrode faster than the fuel can be converted enough. In both cases, the resistance associated with fuel conversion would be reduced.

Cell C differed from Cell B in that it had an active electrode area of $2 \mathrm{~cm}^{2}$ instead of $16 \mathrm{~cm}^{2}$. Therefore, in Figure 7 the observed differences between overpotential trends of the individual process of Cell $\mathrm{B}$ against those of $\mathrm{C}$ can be attributed to the change in fuel utilization. Comparing the trends of both cells in Figure 7 the first important observation is that the total overpotential across the cells drops from Cell B (ca. $118.5 \mathrm{mV}$ in Fuel I at $0.4 \mathrm{~A} / \mathrm{cm}^{2}$ ) to Cell C (ca. $82.8 \mathrm{mV}$ in Fuel $I$ at $0.4 \mathrm{~A} / \mathrm{cm}^{2}$ ). Secondly, the course of the overpotential related to the fuel electrode electrochemical reactions is quantitatively similar for both cells in all fuels. The implication is that in larger cell systems like those in commercial stacks the overpotential related to electrochemical reactions at the fuel electrode will be less determining, than for instance the polarization related to gas conversion.

The next major difference between Cell B and Cell C is the drop in overpotential contributions related to gas conversion in all fuels. At $0.4 \mathrm{~A} / \mathrm{cm}^{2}$ in Fuel I the process is accounting for $47.6 \mathrm{mV}(40 \%)$ of total overpotential in Cell B but in cell $\mathrm{C}$ its contribution is only 11.8 $\mathrm{mV}(14 \%)$. In reformates the drop is from 18.4- to $5.4 \mathrm{mV}$ (16 to 6\%).

For an $\mathrm{H}_{2} / \mathrm{H}_{2} \mathrm{O}$ binary fuel composition, the fuel utilization at a given current density can be calculated based on Faraday's law as displayed in Equation 5.

$$
f_{u}=\frac{j b l R T_{0}}{z F P_{0} \varphi_{H_{2}} /(1000 \cdot 3600)}
$$

In Equation $5 j$ is the current density in $\mathrm{A} / \mathrm{m}^{2}, b$ and $l$ are width and length of the cell in meters perpendicular to and along the flow direct respectively. $R$ and $F$ are the gas and Faraday constants in $\mathrm{J} / \mathrm{mol} / \mathrm{K}$ and As / mol respectively, $T_{0}=273.15 \mathrm{~K}\left(0^{\circ} \mathrm{C}\right), P_{0}$ the atmospheric pressure $(101325 \mathrm{~Pa}), \varphi_{\mathrm{H}_{2}}$ the hydrogen flow rate in liter per hour and $z$ the number of electrons per hydrogen molecule $(=2)$. Although Cell $\mathrm{B}$ and Cell $\mathrm{C}$ have the same width $(\mathrm{b}=0.04 \mathrm{~m})$, they have different lengths $(1=0.04 \mathrm{~m}$ for Cell $\mathrm{B}$ and $0.005 \mathrm{~m}$ for Cell $\mathrm{C})$. Based on Equation 5, this leads to a smaller fuel utilization for Cell $\mathrm{C}$ for a given fuel flow rate $\varphi_{H_{2}}$ and current density $j$, and is reflected in Figure 9. Furthermore, for given $\mathrm{H}_{2}$ and $\mathrm{H}_{2} \mathrm{O}$ inlet mole fractions $x_{i, H_{2}}$ and $x_{i, H_{2} O}$ the average corresponding equivalents under load can be calculated as shown in Equations 6 and 7.

$$
x_{H_{2}, \text { average }}=\left(1-f_{\text {u,average }}\right) \cdot x_{i, H_{2}}
$$
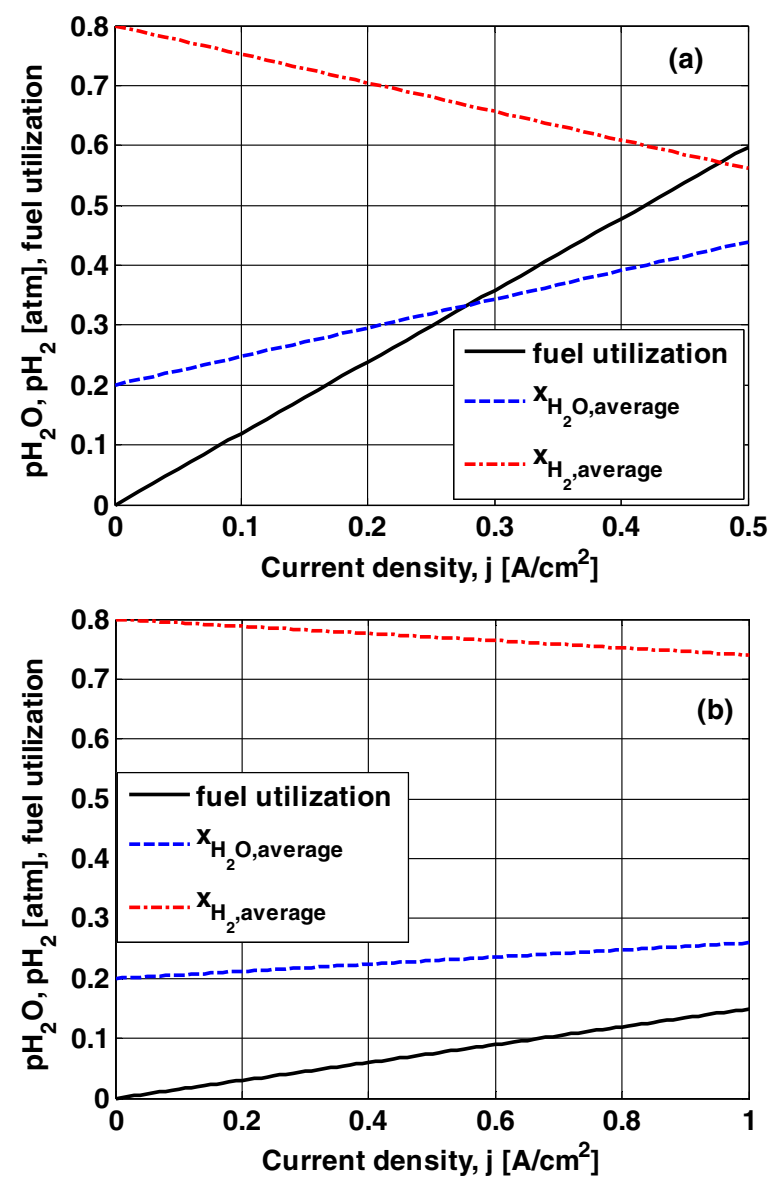

Figure 9. Evolution of fuel utilization and the average steam and hydrogen mole fractions under load for (a) Cell B and (b) Cell C. 

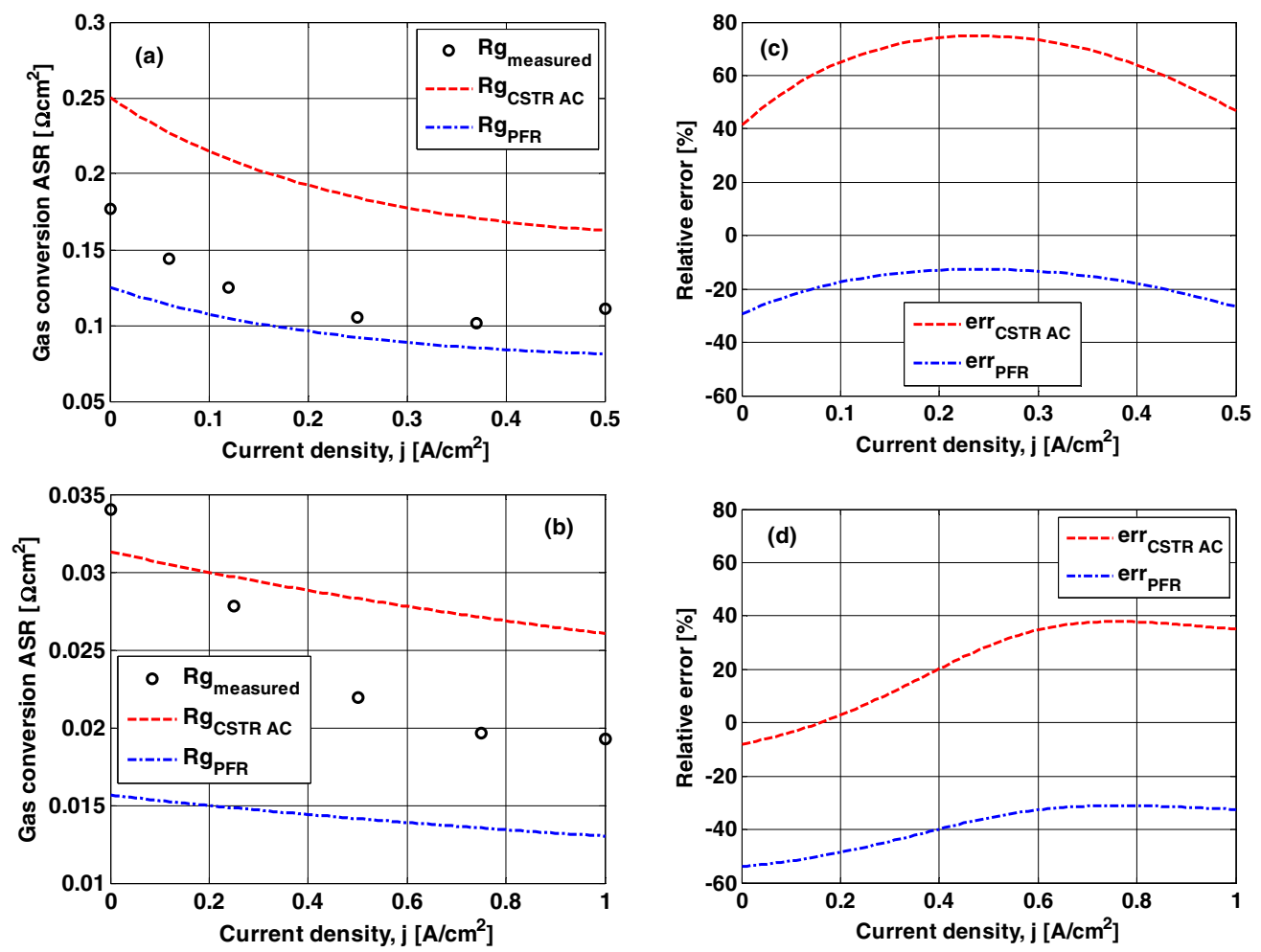

Figure 10. (a) Gas conversion ASR in the $80 / 20 \mathrm{H}_{2} / \mathrm{H}_{2} \mathrm{O}$ fuel mixture at $700^{\circ} \mathrm{C}$ compared with ASR predictions from the plug flow and CSTR AC models for the $16 \mathrm{~cm}^{2}$ Cell B and (b) the $2 \mathrm{~cm}^{2}$ Cell C. (c) Relative errors between model prediction of the gas conversion ASR and measurement for Cell B and (d) Cell C.

$$
x_{\mathrm{H}_{2} \mathrm{O} \text {, average }}=\left(1-x_{\mathrm{H}_{2}, \text { average }}\right)
$$

In Equations 6 and $7 f_{u \text {,average }}$ is the average utilization $\left(=f_{u} / 2\right)$ upon assumption of uniform and linear utilization along the cell. Further, Equation 7 is based on the fact that in the binary $\mathrm{H}_{2} / \mathrm{H}_{2} \mathrm{O}$ fuel mixture, the sum of the component mole fractions amounts to unity. The fuel utilization as well as the average hydrogen and steam mole fractions $x_{\mathrm{H}_{2} \text {,average }}$ and $x_{\mathrm{H}_{2} \mathrm{O} \text {, average }}$ respectively under current have been calculated for Cell $\mathrm{B}$ and Cell $\mathrm{C}$ and displayed in Figures 9a and $9 \mathrm{~b}$ respectively. As can be deduced from Figures $9 \mathrm{a}$ and $9 \mathrm{~b}$, at $0.5 \mathrm{~A} / \mathrm{cm}^{2}$ the fuel utilization in Cell B is $60 \%$ against $7.5 \%$ for Cell $\mathrm{C}$ and corresponding average steam mole fractions are $44-$ and $23 \%$ respectively

The above discussions have shown that at a given current density and flow rate the difference in active electrode area results in a different fuel utilization, which in turn results in differences in average mole fractions of component gases. In a first approximation the consistency of the herein observed gas conversion and diffusion ASRs (in the herein used test set-up) with theoretical predictions will be investigated.

Gas conversion.- - In literature the AC gas conversion ASR has been described for $\mathrm{H}_{2} / \mathrm{H}_{2} \mathrm{O}$ (or $\mathrm{CO} / \mathrm{CO}_{2}$ ) fuel mixtures in a continuously stirred tank reactor (CSTR ${ }^{20}$ type set-up at OCV but also under load for a plug flow reactor (PFR) ${ }^{36}$ set-up. The ASRs for both cases are described by Equation 8, where-by $m$ is 4 for the AC CSTR and 8 for the PFR flow type. This means the gas conversion ASR based on the PFR model is expected to be half of that based on the CSTR model.

$$
R_{g}=\frac{R T}{m F^{2} J_{i}}\left(\frac{1}{x_{i, H_{2}}}+\frac{1}{x_{i, H_{2} O}}\right)
$$

In Eq. $8 R_{g}$ represents the gas conversion area specific resistance, $R$, $T$ and $F$ the gas constant in $\mathrm{J} / \mathrm{mol} / \mathrm{K}$, absolute temperature in $\mathrm{K}$ and Faraday constant in As / mol respectively. The area specific inlet flow rate $J_{i}$ is in $\mathrm{mol} / \mathrm{s} / \mathrm{m}^{2}$, meanwhile $x_{i, H_{2}}$ and $x_{i, H_{2} O}$ are inlet mole fractions of gases $\mathrm{H}_{2}$ and $\mathrm{H}_{2} \mathrm{O}$ respectively.
The gas conversion ASR $R_{g_{\text {measured }}}$ obtained from the CNLS fits at different current densities, and which has been integrated with current density to obtain the corresponding overpotential curves in Figure 7 has been compared with the above described two models for the 16 $\mathrm{cm}^{2}$ cell $\mathrm{B}$ and the $2 \mathrm{~cm}^{2}$ cell $\mathrm{C}$ and results displayed in Figures 10a and $10 \mathrm{~b}$ respectively. In the calculations, the average hydrogen and steam mole fractions calculated using Equations 6 and 7 respectively and displayed in Figures 9a and $9 \mathrm{~b}$ for Cell B and Cell C respectively have been used. The relative errors are displayed in Figures 10c and 10d. From the error curves in Figures 10c and 10d the CSTR AC model shows its best approximation of the measured gas conversion ASR for both cells at OCV. However, Cell B is approximated with a relative error of $40 \%$ against $-8 \%$ for Cell C. Further, whereas the CSTR AC model approximates Cell $\mathrm{C}$ data in the current density range $0-1 \mathrm{~A} / \mathrm{cm}^{2}$ with a maximum error of $37.96 \%$ at $0.76 \mathrm{~A} / \mathrm{cm}^{2}$ Cell $\mathrm{B}$ is approximated with a maximum error of $74.86 \%$ at 0.24 $\mathrm{A} / \mathrm{cm}^{2}$. Thus the geometry of Cell $\mathrm{C}$ under the investigated conditions of temperature, fuel mixture flow rate and $\mathrm{AC}$ signal amplitude of $85 \mathrm{~mA}$ best approaches that necessary for the assumption of CSTR model. Furthermore, the OCV error of Cell C is negative, i.e. the AC CSTR model underestimates the measured data, and this with factor of 1.1. This value suggests that the geometry of Cell $\mathrm{C}$ in the herein used set-up and under the herein investigated conditions better suits those describable with the AC CSTR model than for instance the set-up and conditions in Primdahl et al. ${ }^{20}$ where an underestimation of factor three was observed and the model accorded room for an underestimation of factor two to three.

The plug flow model ${ }^{36}$ gives a much better approximation of Cell $\mathrm{B}$ data with a maximum error of $-29 \%$ at OCV meanwhile Cell C is approximated to a lesser degree, with a maximum error of $-54 \%$ at OCV. Consistent with reported results from measurements done on a similar system, Cell B data lie between the CSTR and plug flow model predictions. ${ }^{29}$

A question which arises from the error curves of both cells is why the plug flow reactor model predicts Cell $\mathrm{C}$ data with a greater error than Cell B. Assuming all of the $85 \mathrm{~mA}$ excitation is converted then 
the corresponding current densities would be 5.3 and $42.5 \mathrm{~mA} / \mathrm{cm}^{2}$ for Cell $\mathrm{B}$ and Cell $\mathrm{C}$ respectively. With these the corresponding $\Delta x$ is $5.1 \mathrm{e}-3$, a value which under load fulfills the condition $\Delta x \ll x_{i}$ better in Cell B than in Cell C (cf. Figures 9a and 9b).

Gas phase diffusion.-Contrary to gas conversion, gas diffusion overpotential contributions increase slightly from Cell B to Cell C in all fuels. Since both gas conversion and gas diffusion are concentration related processes this observation suggests a strong relation between both processes. As demonstrated by Jacobsen et al ${ }^{37}$ for these two processes, a Warburg diffusion impedance is found at higher frequencies, meanwhile the dimensions of the gas volume relative to the support (substrate) determines if the low frequency part tends toward the real axis as a Nernstian diffusion impedance or semicircle.

The relationship in Equation 9 has been suggested ${ }^{27}$ to calculate the ASR of a finite diffusion limitation found around $10-100 \mathrm{~Hz}-$ the frequency range at which the diffusion impedance in this work lies (cf. DRTs in Figures 3 and 6). In this work, the height of the corrugated nickel current collection mesh at the fuel electrode is $850 \mu \mathrm{m}$ against a substrate thickness of ca. $300 \mu \mathrm{m}$ and the flow rate is $7 \mathrm{l} / \mathrm{h}$ in the $\mathrm{H}_{2} / \mathrm{H}_{2} \mathrm{O}$ fuel. Primdahl et al. ${ }^{27}$ could demonstrate that the measured diffusion resistance was that of the stagnant layer above the cell that is not necessarily the case in this work. Primdahl's cell thickness was $40-50 \mu \mathrm{m}$ thick with 1 to 3 layers of Ni felt above the cell and a total flow rate of $61 / \mathrm{h}$.

$$
R_{D}=\left(\frac{R T}{2 F}\right)^{2} \frac{l}{P D_{e f f}}\left(\frac{1}{x_{H_{2}, B}}+\frac{1}{x_{H_{2} O, B}}\right)
$$

In Equation $9 R_{D}$ is the diffusion resistance, $D_{\text {eff }}$ the effective diffusion coefficient, $P$ the pressure, $x_{i, B}$ the molar fraction of species $i$ in the bulk gas, $l$ the bulk height and $\mathrm{R}, \mathrm{T}$ and $\mathrm{F}$ have their usual meanings. From a binary ${ }^{\mathrm{e}}$ gas variation of $\mathrm{H}_{2}$ and $\mathrm{H}_{2} \mathrm{O}$ in the $p \mathrm{H}_{2} \mathrm{O}$ range $10-40 \%$ at $800^{\circ} \mathrm{C}$ in $\mathrm{Cell} \mathrm{B}$, the measured diffusion resistances fitted out through CNLS fit on the ECM in Figure 2 (without the last RQ-element for the reformate process) can be fitted with Equation 9 to obtain the ratio $\frac{l}{D_{e f f}}$. From the fits the value of $31.3 \mathrm{~m} /\left(\mathrm{m}^{2} / \mathrm{s}\right)$ is obtained. This ratio will be assumed to be the same at $700^{\circ} \mathrm{C}$. Primdahl et al. ${ }^{27}$ have suggested that the peak frequency $f_{s}$ of the Warburg impedance is given

$$
f_{s} \approx \frac{2.53 D_{e f f}}{2 \pi l^{2}} .
$$

From the DRTs in Figure 6, the diffusion peak $f_{s}$ is found at ca. $40 \mathrm{~Hz}$ for both cells B and C. With the two values and Equation 10 an effective diffusion coefficient $D_{\text {eff }}$ of $1.027 \cdot 10^{-5} \mathrm{~m}^{2} / \mathrm{s}$ is obtained-a value in the same order of magnitude as the effective diffusion coefficients of $\mathrm{H}_{2}$ and $\mathrm{H}_{2} \mathrm{O}$ in the Ni/YSZ substrate. ${ }^{30}$ With the obtained $D_{\text {eff }}$ and the ratio $\frac{l}{D_{\text {eff }}}$ of $31 \mathrm{~m} /\left(\mathrm{m}^{2} / \mathrm{s}\right)$ a bulk thickness $l$ of $321 \mu \mathrm{m}$. This value matches perfectly with the substrate thickness of both cells B and C of ca. $300 \mu \mathrm{m}$.

A comparison between measured and calculated diffusion ASRs for Cell B and Cell C is displayed in Figure 11a and the corresponding errors in Figure 11b. A major consistency is that the Cell $\mathrm{C}$ calculated values under load are larger than those of Cell $\mathrm{B}$ in accordance with the lower average steam partial pressure under load for Cell C. The next consistency involves the better accuracy in both cells at OCV, with less than $20 \%$ since a linear dependence is only valid for low current densities. ${ }^{27}$ Finally, Cell $\mathrm{C}$ data is approximated with a lower error than Cell B in the whole investigated current density range suggesting that in the used set-up and under the investigated conditions, the geometry of Cell C results to a better simulation of perfect one-dimensional diffusion. Furthermore, as a result of the reduced gas conversion arc in Cell $\mathrm{C}$ the possibility of overlapping with the Cell $\mathrm{C}$ diffusion arc is reduced. This will result in a lower uncertainty on the difference between measured and calculated values. However, although decreased
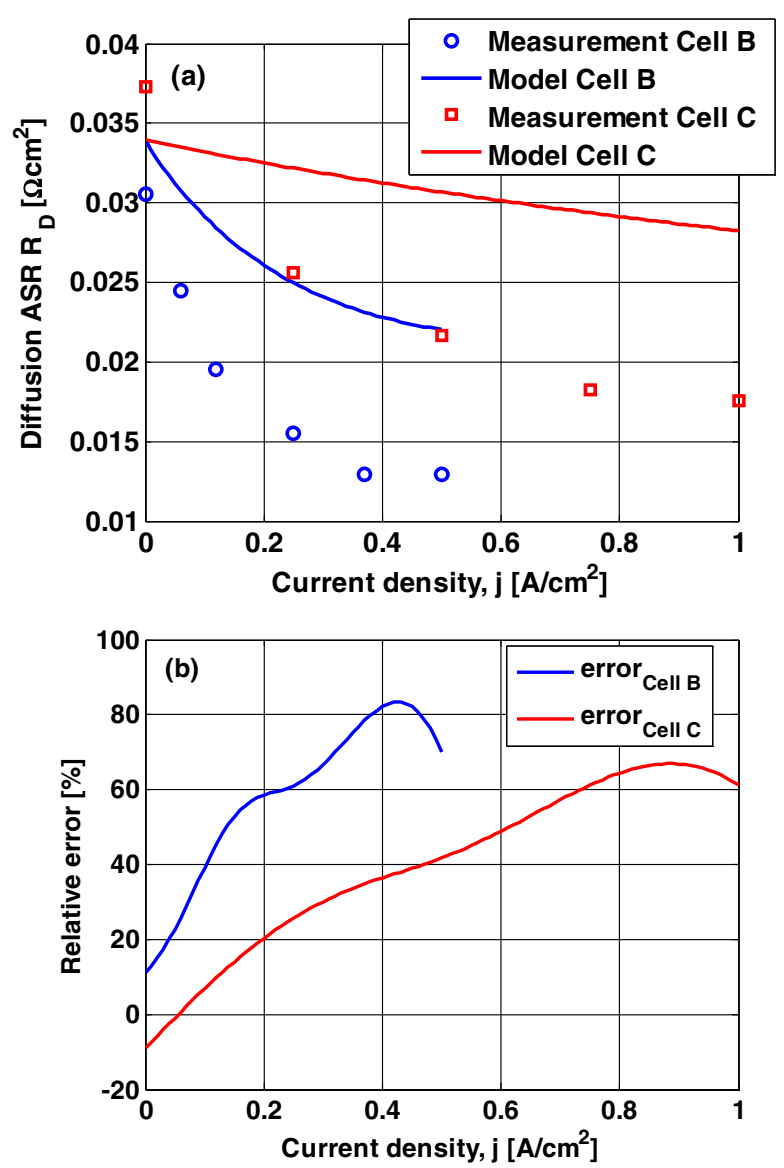

Figure 11. (a) Diffusion ASR in the $80 / 20 \mathrm{H}_{2} / \mathrm{H}_{2} \mathrm{O}$ fuel mixture at $700^{\circ} \mathrm{C}$ (cf. Measurement Cell $\mathrm{X}, \mathrm{X}=\mathrm{B}$ or $\mathrm{C}$ ) compared with ASR predictions from the Equation 9 (cf. Model Cell $\mathrm{X}, \mathrm{X}=\mathrm{B}$ or $\mathrm{C}$ ) (b) Corresponding relative errors.

in size, the shift to higher frequencies and increased overlap with the cathode contribution increases the possibility of overestimating the diffusion ASR in the CNLS fit.

To obtain a more realistic approximation of the gas diffusion ASR under load, microstructural information such as average pore radius of the substrate is required. With this, the Knudsen diffusion coefficient can be determined and together with the bulk diffusion coefficient calculate the molecular diffusion coefficients of $\mathrm{H}_{2}$ and $\mathrm{H}_{2} \mathrm{O}$. With the known bulk height of ca. $300 \mu \mathrm{m}$ the structural parameter $\psi$ can be determined from a binary $\mathrm{H}_{2} / \mathrm{H}_{2} \mathrm{O}$ variation. ${ }^{25}$ The diffusion ASR can then be calculated with Equation 9 where-by instead of $D_{e f f}$ weighting the last term, $\psi$ does and the individual gas components inside the last term are weighted by the corresponding calculated molecular diffusion coefficients. Details are given in elsewhere. ${ }^{25,30}$

A final difference between the cells Cell B and $\mathrm{C}$ is the observation that in Cell $\mathrm{C}$ the ohmic polarization contribution decreases slightly from $20 \mathrm{mV}$ at $0.4 \mathrm{~A} / \mathrm{cm}^{2}$ in Cell $\mathrm{B}$ to $17.4 \mathrm{mV}$. The cathode contact block was the same in the two tests $(4 \times 4 \mathrm{~cm})$, but as the cathode of cell $\mathrm{C}$ was smaller this may lead to small differences in applied mechanical load on the cathode area, assuming that the gold mesh did not adapt to the shape of the cathode, which in turn may yield a slight difference in the contact resistance.

Investigation of low frequency processes in reformate fuels.-To gain further insight into the nature of the low frequency processes, impedance measurements were carried out with a temperature variation from $900^{\circ} \mathrm{C}$ down to $700^{\circ} \mathrm{C}$. Impedance spectra were recorded solely at OCV after allowing a sufficient relaxation time. Further 


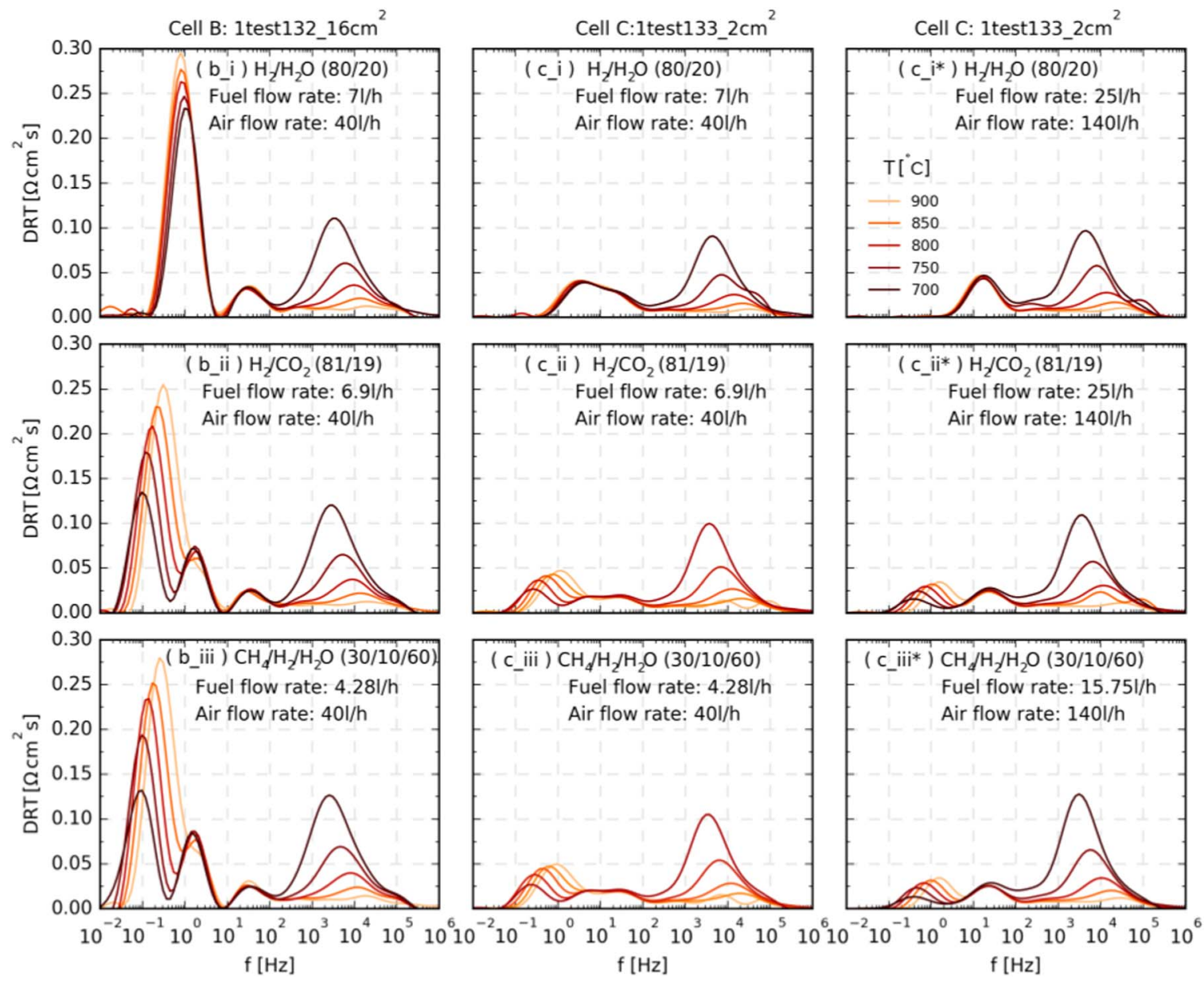

Figure 12. DRTs of cells B and $\mathrm{C}$ calculated from impedance spectra recorded at $\mathrm{OCV}$ in the three fuels $\mathrm{H}_{2} / \mathrm{H}_{2} \mathrm{O}($ Fuel I $), \mathrm{H}_{2} / \mathrm{CO}_{2}($ Fuel II $)$ and $\mathrm{H}_{2} / \mathrm{CH}_{4} / \mathrm{H}_{2} \mathrm{O}$ (Fuel III) in the temperature range $900-700^{\circ} \mathrm{C}$. The curves (c_x** $\mathrm{x}=\mathrm{i}$, ii, iii) show tests on Cell $\mathrm{C}$ with much higher fuel flow rates than the corresponding (c_x, $\mathrm{x}=\mathrm{i}$, ii, and iii) curves.

measurements were conducted at higher fuel flow rate in all three fuel compositions. These are displayed in Figure 12.

Temperature dependency.-The main focus will be the course of the low frequency process i.e. $\mathrm{f}<100 \mathrm{~Hz}$. The frequency range f $>100 \mathrm{~Hz}$ contains the well-studied LSC/CGO composite oxygen electrode ${ }^{38,39}$ in the range $100 \mathrm{~Hz}<\mathrm{f}<1 \mathrm{kHz}$ with an activation energy of $123 \mathrm{~kJ} / \mathrm{mol}^{39}$ and the well investigated ${ }^{19,26,40}$ $\mathrm{Ni} / 8 \mathrm{YSZ}$ fuel electrode ( $\mathrm{f}>1 \mathrm{kHz}$ ) with an activation energy of $105 \mathrm{~kJ} / \mathrm{mol}^{25}$

Considering Cell B alone, Figure 12(b_i) displays the known ${ }^{20,41}$ negative thermal activation for the gas conversion process (peak frequency at $1 \mathrm{~Hz}$ at $900^{\circ} \mathrm{C}$ ). It is important to note the drift of the process to higher frequencies with decreasing temperature. In reformate fuels Fuel II and Fuel III the equivalent process (peak frequency at $2 \mathrm{~Hz}$ at $700^{\circ} \mathrm{C}$ in both reformates) shows a different thermal behavior displaying a weak positive thermal activation with consistent drift to lower frequencies. Based on this observation it is evident that the process is not a pure gas conversion process like the one in $\mathrm{H}_{2} / \mathrm{H}_{2} \mathrm{O}$ fuel. This process by virtue of the used cell geometry and flow rates was absent in Reference 11 and will be termed pseudo-gas conversion in this work. Substrate gas diffusion in all three fuels $10 \mathrm{~Hz}<\mathrm{f}<100 \mathrm{~Hz}$ shows no (or very small) temperature dependence. This is consistent since only a very weak negative thermal activation of $-0.024 \mathrm{eV}^{27}$ is reported in literature.

The low frequency process at $0.1 \mathrm{~Hz}<\mathrm{f}<1 \mathrm{~Hz}$ in reformates shows a pronounced "negative" thermal activation in Cell B. However, contrary to the gas conversion peak in the $\mathrm{H}_{2} / \mathrm{H}_{2} \mathrm{O}$ fuel mixture, the peak drifts to lower frequencies with decreasing temperatures. Evidently the process has a different activation energy from $750^{\circ} \mathrm{C}$ downwards. The drift to lower frequencies is consistent with literature. ${ }^{11}$ However the pronounced negative thermal activation digresses from Kromp's results which were based on investigations done on $1 \mathrm{~cm}^{2}$ SOCs and no thermal activation of the process detected. ${ }^{11}$ The herein observed "negative" activation energy is related to an overlapping of the reformate process (catalytic conversion + diffusion in the substrate) and the gas conversion process (in the gas channel). Due to the RWGS of $\mathrm{CO}$ and steam reforming of $\mathrm{CH}_{4}$ the electrochemical active $\mathrm{Ni}$ does not "see" the $p \mathrm{H}_{2}$ value that prevails in the gas channel in case of Fuel II and III. Further it is important to note that in Reference 11 the total fuel flow rate of $250 \mathrm{sccm}$ flowing over an active electrode area of $1 \mathrm{~cm}^{2}$ corresponds to an effective flow rate of $15 \mathrm{l} / \mathrm{h}$ per unit area. However, the reformates Fuel II and Fuel III in Cell B are having flow rates per unit active electrode area of $0.43 \mathrm{l} / \mathrm{h}\left(=6.9 \mathrm{l} / \mathrm{h} / 16 \mathrm{~cm}^{2}\right)$ and $0.27 \mathrm{l} / \mathrm{h}\left(=4.28 \mathrm{l} / \mathrm{h} / 16 \mathrm{~cm}^{2}\right)$ respectively.

For Cell C, which has $2 \mathrm{~cm}^{2}$ active electrode area instead of 16 $\mathrm{cm}^{2}$, a drastic reduction in all processes below $10 \mathrm{~Hz}$ (i.e. the gas concentration related impedance contributions) could be registered in all three fuel mixtures. All processes in Cell B with $16 \mathrm{~cm}^{2}$ active electrode area are present and identifiable in Cell $\mathrm{C}$ despite the drastic reduction in peak sizes.

Fuel flow rate dependency.-The flow rates of the three fuels were increased from 7, 6.9 and 4.28 1/h in the fuels Fuel I, Fuel II and Fuel III respectively to 25,25 and $15.75 \mathrm{l} / \mathrm{h}$ respectively. It was ensured that the cell voltage as well as equilibrium concentration of the reformate 
fuels remained unchanged. By considering the flow rates per unit active electrode area, the reformates Fuel II and Fuel III have 12.5 1/h and $7.88 \mathrm{l} / \mathrm{h}$ respectively against $15 \mathrm{l} / \mathrm{h}$ in Reference 11 . From Figure 12 (c_i*) it can be seen that the gas conversion peak in Fuel I appears to vanish. This is consistent with expectation ${ }^{37}$ since according to Equation 8 the gas conversion ASR decreases with increasing flow rate and given that the peak frequency of the RQ-element is given by $\frac{1}{2 \pi \sqrt[n]{R Y_{0}}},{ }^{27}$ the decreasing ARS implies a drift to higher frequencies. The much diminished ASR most probably vanishes beneath / overlaps the diffusion peak. A slight increase in the size of the gas diffusion peak was also observed.

Of particular interest is the behavior in the reformate fuels as the pseudo-gas conversion peak does not only "vanish" but drifts to higher frequencies with change in fuel flow rate and appears to merge with the diffusion peak (that does not change with fuel flow rate, cf. Equation. 9) into a single peak. It should be noted both processes are still present in the cell but as they change their relaxation frequency with operating conditions the overlapping becomes stronger and the two peaks cannot be separated in the DRT. The new "diffusion" peak is slightly larger than either of the peaks. The reformate peak at $\mathrm{f}<10 \mathrm{~Hz}$ is reduced but clearly does not disappear. Its temperature dependence is similar to that observed by Kromp et al. in $1 \mathrm{~cm}^{2}$ cells. However, Kromp describes the process as not exhibiting thermal activation behavior and describes the process as related to a coupling of shift reaction and gas phase transport within the substrate.

\section{Conclusions}

Through detailed impedance spectroscopy it could be shown that the kinetic performance of the Ni/8YSZ fuel electrode of solid oxide cells in $\mathrm{H}_{2} / \mathrm{CO}_{2}$-based reformate fuels is comparable to that in $\mathrm{CH}_{4} / \mathrm{H}_{2} \mathrm{O}$-based reformate fuel. In the hydrogen/steam fuel, under comparable conditions of temperature and open circuit voltage the kinetic performance was 5- and $7 \%$ faster than in the $\mathrm{H}_{2} / \mathrm{CO}_{2}$ - and $\mathrm{CH}_{4} / \mathrm{H}_{2} \mathrm{O}$-based reformate compositions respectively at $500 \mathrm{~mA} / \mathrm{cm}^{2}$. Although equivalent circuit modeling enabled quantification of the overpotential contributions from the oxygen electrode, electrolyte and mass transport, the obtained current density vs. overpotential curves could not be further analyzed for a possible analytic description as no corrections were made for steam content and temperature increase with increasing current density. There is currently ongoing work on specially designed cells to address the two contributions. It could further be shown that a finer electrode microstructure had a positive influence on the electrode performance in all fuels, displaying 19\% faster kinetics in $\mathrm{H}_{2} / \mathrm{H}_{2} \mathrm{O}$ fuel. A reduction of the active electrode geometric area had no influence on the kinetic performance, as expected.

The gas conversion ASRs of the $16 \mathrm{~cm}^{2}$ Cell B and $2 \mathrm{~cm}^{2}$ Cell C determined from CNLS fits in $\mathrm{H}_{2} / \mathrm{H}_{2} \mathrm{O}$ fuel mixture were compared with model predictions from literature. It could be shown that the plug-flow model described Cell B data better than the AC CSTR model across the whole current density range. On the other hand, the CSTR model described Cell $\mathrm{C}$ data better in the range $0-0.5 \mathrm{~A} / \mathrm{cm}^{2}$ after which the plug flow reactor model became better. The measured diffusion ASR for the $4 \times 4$ and $0.5 \times 4 \mathrm{~cm}^{2}$ cells were compared with theoretical predictions. The ASR of the cell with the smaller active electrode area was better approximated by the used literature model, although the in size diminished conversion arc was drifted to higher frequencies and had overlapped more with the diffusion arc.

It could further be shown that in the reformate fuels the process with second lowest characteristic frequency merges with the gas diffusion process into a single DRT peak with no detectable thermal activation. Meanwhile, contrary to current status in literature, the process with the lowest characteristic frequency displayed a negative temperature dependence which changed at temperatures below $750^{\circ} \mathrm{C}$. The ASR of this process decreased with decreasing electrode area and increased fuel flow rate, i.e. with decreasing fuel utilization.

\section{Acknowledgments}

The authors thank all laboratory staff in the SOFC research laboratories at DTU Energy, for all cell test related assistance. Particular acknowledgement to Karen Brodersen and all colleagues involved in the development of the used cells. We gratefully acknowledge financial support from Energinet.dk through the ForskEL programme "Towards Smart Grid Ready SOFC" contract no 2012-1-10747 and "Solid Oxide Fuel Cells for the Renewable Energy Transition" contract no 2014-1-12231. We would also like to thank all the members who participated in the above projects for the interesting discussions during internal presentations of these results.

\section{References}

1. Danish Energy Agency and Energinet.dk (2014, January). Technology Data for Energy Plants., (2014).

2. R. Payne, J. Love, and M. Kah, ECS Trans., 25, 231 (2009)

3. L. Zhao et al., ECS Trans., 71, 131 (2016).

4. B. Dziurdzia, Z. Magonski, and H. Jankowski, IOP Conf. Ser. Mater. Sci. Eng., 104, 12020 (2016).

5. US Department of Energy, Solid Oxide Fuel Cells Technology Program Plan (2013, January), (2013).

6. A. Bauen, D. Hart, and A. Chase, Int. J. Hydrogen Energy, 28, 695 (2003).

7. V. Karakoussis, N. Brandon, M. Leach, and R. van der Vorst, J. Power Sources, 101, 10 (2001).

8. H. Timmermann, W. Sawady, R. Reimert, and E. Ivers-Tiffée, J. Power Sources, 195, 214 (2010).

9. A. Weber, Solid State Ionics, 152-153, 543 (2002).

10. A. Leonide, A. Weber, and E. Ivers-Tiffée, ECS Trans., 35, 2961 (2011).

11. A. Kromp, A. Leonide, A. Weber, and E. Ivers-TiffeFe, J. Electrochem. Soc., 158, B980 (2011).

12. A. Kromp, H. Geisler, A. Weber, and E. Ivers-Tiffée, Electrochim. Acta, 106, 418 (2013).

13. A. Dicks, J. Power Sources, 71, 111 (1998).

14. P. H. Lasen and K. Brodersen, US Pat. 20080124602 (2007).

15. A. Hauch, K. Brodersen, M. Chen, and M. B. Mogensen, Solid State Ionics, 293, 27 (2016).

16. S. D. Ebbesen, C. Graves, A. Hauch, S. H. Jensen, and M. Mogensen, J. Electrochem. Soc., 157, B1419 (2010).

17. B. Boukamp, Solid State Ionics, 74, 85 (1994).

18. B. Boukamp, J. Electrochem. Soc., 142, 1885 (1995).

19. A. Leonide, V. Sonn, A. Weber, and E. Ivers-TiffeF́e, J. Electrochem. Soc., 155, B36 (2008).

20. S. Primdahl and M. Mogensen, J. Electrochem. Soc., 145, 2431 (1998).

21. A. Leonide, A. Weber, and E. Ivers-Tiffée, ECS Trans., 35, 2961 (2011).

22. A. Hagen, G. B. Johnson, and P. Hjalmarsson, J. Power Sources, 272, 776 (2014).

23. H. Schichlein, J. Appl. Electrochem., 32, 875 (2002).

24. C. Graves, RAVDAV Data Anal. Software, Version 0.9 .8 (2014).

25. A. Leonide, Y. Apel, and E. Ivers-Tiffee, in ECS Transactions, 19, 81, ECS (2009).

26. V. Sonn, A. Leonide, and E. Ivers-TiffeF́e, J. Electrochem. Soc., 155, B675 (2008).

27. S. Primdahl and M. Mogensen, J. Electrochem. Soc., 146, 2827 (1999).

28. A. Bertei, G. Arcolini, C. Nicolella, and P. Piccardo, ECS Trans., 68, 2897 (2015).

29. S. D. Ebbesen and M. Mogensen, ECS Trans., 50, 167 (2013).

30. J.-C. Njodzefon, D. Klotz, A. Kromp, A. Weber, and E. Ivers-Tiffée, J. Electrochem. Soc., 160 (2013).

31. A. Leonide, SOFC Modelling and Parameter Identification by means of Impedance Spectroscopy- PhD Thesis, Karlsruhe Institute of Technology, KIT Scientific Publishing, Karlsruhe, (2010).

32. S. D. Ebbesen, R. Knibbe, and M. Mogensen, J. Electrochem. Soc., 159, F482 (2012).

33. A. Leonide, S. Hansmann, A. Weber, and E. Ivers-Tiffée, J. Power Sources, 196, 7343 (2011).

34. J.-C. Njodzefon, B. R. Sudireddy, J. Hjelm, and C. Graves, ECS Trans., 68, 1169 (2015).

35. A. Weber and E. Ivers-tiffée, Proc. 11th Eur. SOFC SOE Forum, 2014, A1307 (2014).

36. S. H. Jensen, A. Hauch, P. V. Hendriksen, and M. Mogensen, J. Electrochem. Soc., 156, B757 (2009).

37. T. Jacobsen, P. V. Hendriksen, and S. Koch, Electrochim. Acta, 53, 7500 (2008).

38. J. Nielsen, P. Hjalmarsson, M. H. Hansen, and P. Blennow, J. Power Sources, 245 , 418 (2014).

39. A. J. Samson, P. Hjalmarsson, M. Søgaard, J. Hjelm, and N. Bonanos, J. Power Sources, 216, 124 (2012).

40. M. Brown, S. Primdahl, and M. Mogensen, J. Electrochem. Soc., 147, 475 (2000).

41. S. Primdahl and M. Mogensen, J. Electrochem. Soc., 144, 3409 (1997). 